\title{
Energy Cycles: Nature, Turning Points and Role in England Economic Growth from 1700 to 2018
}

\author{
Marinko SKARE ${ }^{1 *}$, Matgorzata PORADA-ROCHON ${ }^{2}$ and Sanja BLAZEVIC-BURIC ${ }^{3}$
}

\author{
Authors' affiliations and addresses: \\ ${ }^{1}$ Juraj Dobrila University of Pula, Faculty of \\ economics and tourism "Dr. Mijo Mirkovic", \\ Zagrebacka 30, 52100 Pula, 38552377000 , \\ Croatia \\ e-mail: mskare@unipu.hr \\ ${ }^{2}$ University of Szczecin, Faculty of Economics, \\ Finance and Management, Szczecin, Poland \\ e-mail: malgorzata.rochon@wp.pl \\ ${ }^{3}$ Juraj Dobrila University of Pula, Faculty of \\ economics and tourism "Dr. Mijo Mirkovic", \\ Zagrebacka 30, 52100 Pula, Croatia \\ e-mail: sblazev@unipu.hr \\ *Correspondence: \\ Marinko Skare, Juraj Dobrila University of Pula, \\ Zagrebacka 30, 52100 Pula, 38552377000 , \\ Croatia \\ e-mail: mskare@unipu.hr
}

How to cite this article:

Skare, M., Porada-Rochon', M. and BlazevicBuric, S. (2021). Energy Cycles: Nature, Turning Points and Role in England Economic Growth from 1700 to 2018. Acta Montanistica Slovaca, Volume 26 (2), 281-302.

DOI:

https://doi.org/10.46544/AMS.v26i2.08

\begin{abstract}
Business cycles are among the most discussed topics in social sciences. Environmental changes, heatwaves and natural disasters as consequences of anthropogenic activities are headwinds to future economic growth and development. There is an ongoing debate on environmental degradation and its socio-economic impact. Here we investigate the existence of primary energy (coal, gas, oil, nuclear, solar, thermal, wind) cycles in England from 1700 to 2018. Using turning points methodology (Harding \& Pagan, 2002), we isolate energy cycles and explain their phase characteristics. Offering empirical evidence of energy cycles existence should assist policymakers to gain additional quantitative knowledge to understand and contain business cycles. Fossil fuels energy cycles are closely linked to business cycles, but renewable energy cycles are pushing forward, targeting the leading role. Energy cycles are the missing link in the literature needed to understand business cycles and future economic development. In this study, we supply knowledge for understanding energy cycles and their relationship to the business cycles. The estimated concordance index reveals a systematic relationship between energy and business cycles with conclusive results. Energy cycles in this century will become a major force driving socio-economic events. Managers in the firms and policymakers on the macro-level will need knowledge on energy cycles since tracking energy cycles soon will become more important to tracking business cycles. To this end, our study contributes to the study of energy cycles as the source of business cycles.
\end{abstract}

\section{Keywords}

Energy cycles, Turning points, Concordance index, Primary energy, Business cycles 


\section{Introduction}

The relationship between energy and growth is a subject of intensive inquiry. Until now, research on this subject has concentrated on the relationship between $\mathrm{CO} 2$ (carbon dioxide) emissions and economic growth, as well as the impact of electricity and renewable energy on economic growth. Not only for policymakers but also for practitioners preparing for the energy transition, it is critical to understand the role of energy in economic growth. Economic growth models and policies must adapt to changing conditions, resulting in the development of a new growth model.

The role of energy in growth is studied in Keen et al. (2019) using energy-based (exergy) production function models (Heun \& Brockway, 2019). Our study aims to investigate, quantify, and explain the turning points in energy consumption measuring (for the first time that we are aware of) and deriving energy cycles. Our findings confirm the concept of energy cycles. Energy cycles exist, and they show different mechanics for different energy sources. Without establishing energy cycles, policymakers and business practitioners will be limited in designing efficient economic policies to achieve growth. Assuring future sustainable development demands quantitative knowledge on energy cycles. The article's statistical analysis of time-series data for the United Kingdom (UK) from 1700 to 2018 supports the energy cycles idea. Contribution to the field of knowledge results from its use of the most extensive time-series data on energy consumption (1700-2018) and the most advanced modelling approaches (cycle measurement). To shed new insight on energy cycles, we evaluate primary energy cycles in the UK using data on primary energy consumption. We seek to build a novel study field by combining historical time series data, cutting-edge cycle modelling tools, and a modified Harding and Pagan approach (Cardinale \& Taylor, 2009).

In seminal publications (Ayres et al., 2003; Ayres \& Warr, 2005; Ayres \& Voudouris, 2014; Warr et al., 2010; Keen et al., 2019; Santos et al., 2018), the authors propose a new form of aggregate Cobb-Douglas function (Cobb $\&$ Douglas, 1928). Their work reaffirms energy's significance in production, paving the door for future 'energybased' growth models. Positive energy has been shown to contribute to economic growth in 66 nations between 1986 and 2005 (Sharma, 2010). There is evidence to imply that a link exists between energy demand/supply and economic growth (Apergis et al., 2010; Apergis \& Payne, 2009a, 2009b, 2009c; Ozturk \& Acaravci, 2013; WoldeRufael, 2009, 2014; Coers \& Sanders, 2013; Richard, 2012; Jalil, 2014; Mohammadi \& Parvaresh, 2014).

However, the data regarding the precise nature of the relationship between energy supply/demand and economic growth is mixed. Most existing research points to a positive relationship between energy and growth. The evidence for energy's efficacy in growth differs considerably, ranging from research supporting the energygrowth theory to studies demonstrating energy-growth decoupling (Sharma et al., 2019). (Moreau \& Vuille, 2018). Economic growth and energy use are intricately connected, as has long been recognised. Energy consumption increases as the economy grows; when energy is scarce, GDP (gross domestic product) growth slows. According to studies conducted by Foxon (2018), Fouquet $(2008,2018,2019)$, this was the actual scenario that existed during the formation of ancient towns and trade markets.

Recently, Sharma et al. (2019) concluded a multi-year study project in which they investigated the supply and demand for 55 different types of energy in 30 different sectors across 146 different nations. According to the most current global energy outlook, we are witnessing a decoupling of economic growth and energy demand. Not only is it critical for macroeconomic management to understand the underlying relationship between energy and growth, but it is also critical for company managers to address energy cycles appropriately soon. Our study emphasises the critical role of empirical evidence in fully comprehending the nature of energy cycles. The longrun relationship between energy cycles and growth in the UK over the previous three hundred years is examined here.

The findings of this study cast doubt on the standard concept of a long-term energy-growth link. Between countries, the energy cycles-growth nexus is more important than the energy-growth link itself. The level of synchronisation between primary energy consumption (cycles) and economic growth determines future growth rates. To understand the nature of the business cycles first, we must explore energy cycles. It is volatility in energy consumption to drive economic fluctuations significantly. There exists a strong causality link between economic shocks and energy consumption - a bidirectional link. Movements in energy prices cause global fluctuations in energy consumption as well economic fluctuations and potential crises. Energy cycles, in their nature, can be regarded as supranational cycles having global socio-economic implications. Empirical evidence on the existence of countries energy cycles, like the one we isolate for the UK, provide quantitative knowledge and proof to support future studies in the field of energy cycles.

We intend to build on prior research on the energy-growth nexus, which has shown inconclusive results. The primary objective of this study is to identify and explain (using empirically rigorous data) energy cycles and their link with growth. The central research question is to explain the role of energy cycles on economic growth in the past and future. Our research aims to establish a causal link between energy cycles and growth. To do this, we suggest a modified method for energy cycles identification. A novel element of our research is in measuring primary energy cycles and their synchronisation to growth. Our innovative approach in the subject of energy cycles-growth link is motivated by recent developments. To accomplish this, we employ long time-series data and state-of-the-art cycles measuring techniques from 1700 to 2018 in the UK. 
The paper begins with a survey of the literature on the energy-GDP (gross domestic product) nexus. Section three discusses the material and method used throughout the study. Section four has a detailed description of the empirical results. Section five summarises and discuss the study's findings. The conclusion highlights the study's major results and practical contributions, as well as making recommendations for further research.

\section{Literature Review on Energy and Growth}

The energy cycle is not an area explored in literature. Rather, the relationship between energy and economic growth is studied. However, the results of the research are not consistent and unambiguous. The first step in modelling energy price shocks in a Real Business Cycle framework was examined by Kim and Loungani (1992).

The literature on the subject is confused about the effects of the energy transformation. On the one hand, it points to opportunities for economic growth, and on the other hand, it points to excessive financial outlays. Moreover, in 2005, most EU countries decoupled economic growth from energy consumption.

Observation of the global energy transition leaves no doubt that the rise of renewables will change the relationship between countries and drive key changes in the world's economies (IRENA, 2019). Moreover, economic growth will be facilitated for countries that are able to innovate more in renewables, batteries, and electric cars (Hafner \& Tagliapietra, 2020). According to an OECD report 2017, economic growth must be looked at in the long term, inclusive growth must be considered, and sources of growth must be economically, socially, and environmentally.

An analysis of the 10 largest energy-consuming countries in the world shows a positive relationship between economic growth and energy consumption, although there are significant differences between the economic states of each country (Shahbaz et al., 2018).

Looking at 75 net energy-importing countries for the period 1990 to 2012, they find that there is a positive and statistically significant relationship between energy consumption and economic growth over the long term. When a country's dependence on imports decreases, then energy consumption contributes to economic growth (Kim \& Loungani, 1992). Also, looking at the USA economy argued a strong correlation between growth in electricity use and GDP (Arora \& Viskovsky, 2014).

Considering the Swedish economy, Stern and Kander (2012) confirm that the main drivers of economic growth in the $19^{\text {th }}$ and early $20^{\text {th }}$ Centuries were increases in energy use as well as energy - augmenting technological change. Stern et al. (2016) highlighted that electricity access is likely not sufficient for economic growth, but they find that electricity use and GDP are those variables that share the same trend.

Considering Bulgarian economy 1999-2016, Vasilev (2018) introduce a pro-cyclical endogenous utilisation rate of physical capital stock into a real business cycle model augmented with a detailed government sector. They investigated the energy use for cyclical fluctuations in Bulgaria, considering the quantitative importance of the endogenous depreciation rate and the capital use mechanism operating through energy use. They find that a positive shock to energy prices in the model works as a negative technological shock.

The study of China's economy showed while energy consumption causes economic growth by Granger's method in the short run, but the opposite is true in the medium run. However, in the long run, a bidirectional causal relationship is proven (Ha et al., 2018).

Interesting results were presented by analysing nineteen selected African countries from 1971 to 2014. Results show an asymmetric relationship between energy consumption and economic growth. Moreover, it depends on the phases of the economic cycle. Given a period of economic expansion, positive shocks to energy consumption have a positive and significant effect on economic growth in the long run but have a weak positive effect in the short run. In contrast, Negative shocks in energy consumption have a negative and significant impact on economic growth in the long run but already have a significant and positive impact in the short run (Kouton, 2019). Considering the business cycle in the US economy, it was found that permanent shocks explain the bulk of the variations in energy consumption and output at business cycle horizons (Narayan, 2011).

The study on the example of Turkey indicates that there is no evidence of causality between energy consumption and GDP (Altinaya, 2004).

\section{Material and Methods}

The principal goal of our study is to isolate energy cycles using long time series data for the UK. The first step in decomposing time series in a search for energy cycles is to use Bry \& Boschan (1971), Harding \& Pagan (2002, 2003) turning point procedure. To this end, annual data are converted to quarterly data (higher frequency) using a Chow-Lin regression frequency conversion (Chow \& Lin, 1971). Identifying turning points in time series data to isolate cycles requires high-frequency data (quarterly). Converted quarterly data were checked against original annual data fitting at best with a correlation coefficient of 0.99 . Converted quarterly data show high reliability and no bias, so to proceed with cycle extraction according to standard procedures for time series data decomposition. We use data sources to construct this study database, including Department for Business, Energy, and Industrial Strategy (2019), Church (1986; Flinn \& Stoker, 1984; Fouquet, 2008; Prest \& Adams, 1954; Stone 
et al.,1954). The software and procedure we use here in the analysis is STATA 16MP and Bracke (2012) business cycle dating algorithm.

To study energy cycles, this study uses a battery of standard econometric filters (Cardinale \& Taylor, 2009; Pollock, 2015), unobserved component decomposition (Harvey, 1990) and spectral analysis (Sella et al., 2013). Energy cycle decomposition requires extended time-series data, so data availability is the key factor for a country's candidate. Extensive reviews on historical energy production and consumption global databases put forward Great Britain (UK) as a suitable candidate for the analysis. Beyond data availability, the UK is a perfect study candidate since its key role in the industrial revolution process and leadership role in energy transition and decarbonisation after 1960. Another prospective country is the US, but the data for the US are available from 1775 on a five-year basis and only after 1949 on an annual and monthly basis. Cycle extraction demands high levels of data reliability, and thus the UK is selected as a candidate for the study. Cycle decomposition demands at least data beyond the Kondratieff cycle (Modis, 2017) of 60 years. Due to the energy transition witnessed after 1960, primary energy cycles could not be examined adequately. Since the purpose of the study is to assert (or decline) primary energy cycle existence, an extended time series data sample is needed. For this purpose, this study uses Fouquet (2020) database. This study presents a novel attempt to isolate primary energy cycles, so this pioneering approach involves high data reliability. Fouquet (2020) offers historical energy data for the UK from 1700 to 2018 on UK energy consumption, energy prices and carbon dioxide emissions. Literature on cycles in economics look at the pattern, stages in economic activity to isolate a long-run tendency. Forecasting economic activity is the final goal in measuring economic activity and growth cycles (Zarnowitz \& Ozyildirim, 2006). Prolonged growth cycle phases cause jumps in the series bringing the level of economic activity on higher/lower dynamic paths. It is the purpose of this study to scan at patterns, phases that could explain amplitudes (expansion, contraction) in primary energy consumption. To isolate and understand primary energy cycles could help infer the process of energy transition and its determinants. This could help learn how primary energy consumption changed over time to mitigate growth externalities. The starting point to decarbonisation is to prove or disprove primary energy cycles.

Non-renewable primary energy is a driving growth factor for a long. This study decomposes time series data on primary energy availability and consumption in the UK from 1700 to 2018. To this end, the study uses data on coal, petroleum, natural gas, nuclear energy, hydro energy, wind and solar energy, thermal energy, and bioenergy in the UK. A study of an individual cycle starts with the graphical data examination. Figure 1 shows the availability and consumption of primary energy in the UK from 1700 to 2018 (inland consumption for energy use).

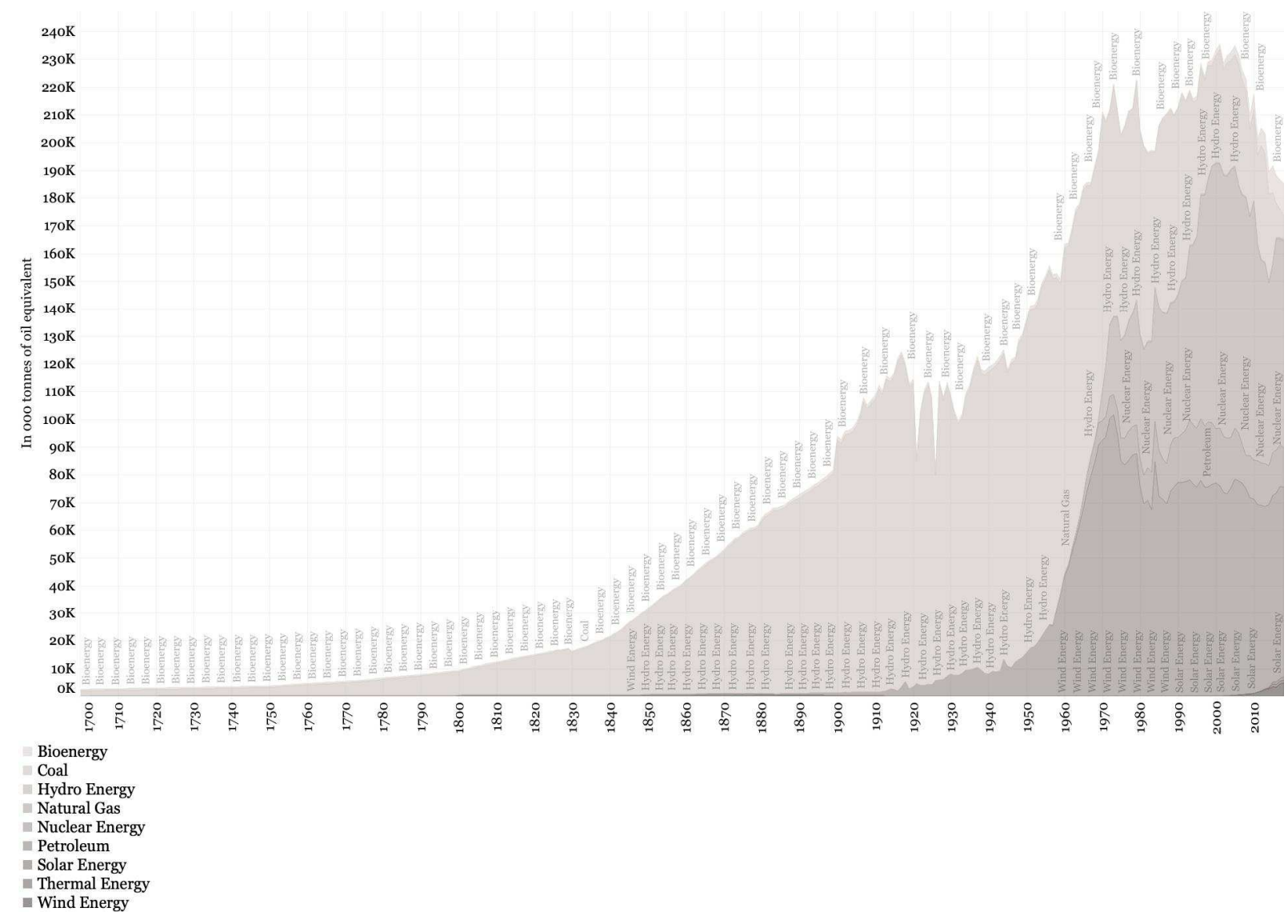

Fig. 1. Availability and consumption of primary energy in the UK, 1700-2018 
Source: Authors' own research from data Department for Business, Energy and Industrial Strategy (2019), Church (1986; Flinn \& Stoker, 1984; Fouquet, 2008; Prest \& Adams, 1954; Stone et al.,1954).

Figure 1 shows a singular exponential growth shape in primary energy consumption. The graph portrays the dynamics in energy transition, from bioenergy to solar energy, through all nine types of energy sources. Coal was the primary source of energy from 1700 to 1971 after being replaced by petroleum (1971), natural gas (1993) and nuclear energy (2016). However, the energy transition from fossil fuels to renewable energy is still far going (see Figure 2).

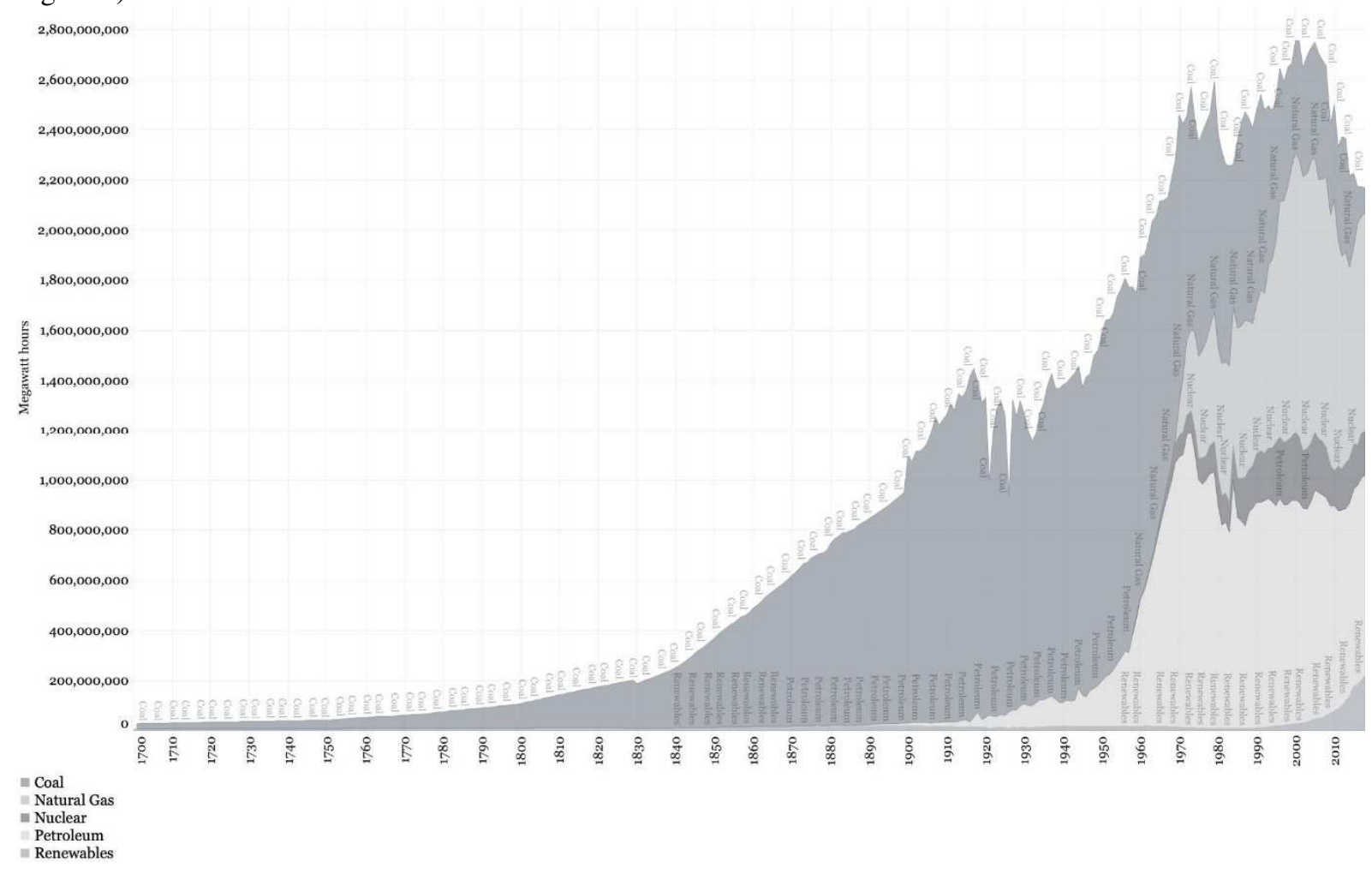

Fig. 2. Energy Consumption Sources in the UK, 1700-2018

Source: Authors' own research from data Department for Business, Energy and Industrial Strategy (2019), Church (1986; Flinn \& Stoker, 1984; Fouquet, 2008; Prest \& Adams, 1954; Stone et al.,1954).

Figure 2 shows energy consumed from different sources in the UK over three centuries. The booming of renewable energy sources is evident after 1990. The amount of energy consumed coming from fossil fuels is still dominant. Not only, in the year 1700 in the UK, fossil fuels accounted for $71.14 \%$ of the total energy consumed. In 2018, energy consumed in the UK occurring from fossil fuels was $80.41 \%$. The share of renewable energy in the total energy consumed in the UK increased from 8.78\% in 1989 to $17.28 \%$ in 2018. Such an important shift in energy transition decreased total carbon emissions (gas, non-fuel, oil) from 582 million tonnes in 1989 to 366 in 2018. Carbon emissions dropped by $-37.11 \%$ or a $-1.58 \%$ annual decline rate. That is, an insuring sign for the decarbonisation undertaking in England.

\section{Results}

Table 1 displays coal energy cycles in the UK from 1700-2018 using the cycle dating algorithm of Harding \& Pagan (2002). The algorithm, through time-series data turning point identification, isolates 32 contraction phases (peak to trough) and 32 expansion phases (previous trough to peak). The expansion phase, on average, lasts 29 quarters and the contraction phase 7 quarters. The expansion phase, as expected for the coal role in UK past growth, is four times the average contraction cycle length. The average cumulative movement in expansion is sixteen times the magnitude of the cumulative movement in contraction (longer average duration). The average amplitudes for expansion and contraction are similar in magnitude. The average amplitude for expansion is $20.3 \%$ and contraction $-11.4 \%$. A fall in coal consumption (contraction) is almost twice matched during the expansion phase. The downfall in coal consumption is quickly replaced (and surpassed) by a strong upswing in coal consumption. This points to the Pareto inefficiency in coal consumption since a decline in the coal consumption (the contraction phase) is replaced by over increased coal consumption (expansion phase) and not by alternative sources of energy. For downswings, the average cumulative movement in coal consumption is $-57.9 \%$. Thus, the cumulative decline 
of coal consumption during contraction amounts to $-57.9 \%$. Actual loss in coal consumption (-57.9\%) is far below actual gains in coal consumption $(+1601.3 \%)$ during respective phases. Excess estimation in coal consumption during contraction and expansion phases reflects the speed (dynamics) of change in each phase. High positive divergence (excess in the expansion of 160\%) reflects speedy revival in the initial part of an expansion phase. During the contraction phase, an excess measure (high negative divergence -269\%) reveals a rapid decline in coal consumption in the early stage of a downswing.

Tab. 1. Turning Points and Coal Cycles in the UK from 1700 to 2018

\begin{tabular}{|c|c|c|c|c|c|}
\hline \multicolumn{2}{|c|}{ REFERENCE DATES } & \multicolumn{4}{|c|}{ DURATIONS IN QUARTERS } \\
\hline \multirow[t]{2}{*}{ Peak } & \multirow[t]{2}{*}{ Trough } & \multirow{2}{*}{$\begin{array}{c}\text { Contraction } \\
\text { Peak to Trough }\end{array}$} & \multirow{2}{*}{$\begin{array}{c}\text { Expansion } \\
\text { Previous Trough } \\
\text { to this Peak }\end{array}$} & \multicolumn{2}{|c|}{ Cycle } \\
\hline & & & & $\begin{array}{l}\text { Trough from } \\
\text { previous Trough }\end{array}$ & $\begin{array}{l}\text { Peak from } \\
\text { Previous Peak }\end{array}$ \\
\hline 1723Q4 & 1724Q4 & 4 & & & \\
\hline 1765Q4 & 1766Q4 & 4 & 164 & 168 & 168 \\
\hline $1829 \mathrm{Q} 4$ & 1830Q4 & 4 & 252 & 256 & 256 \\
\hline 1900Q4 & 1901Q4 & 4 & 280 & 284 & 284 \\
\hline 1907Q4 & 1908Q4 & 4 & 24 & 28 & 28 \\
\hline 1911Q4 & 1912Q4 & 4 & 12 & 16 & 16 \\
\hline 1913Q4 & 1914Q4 & 4 & 4 & 8 & 8 \\
\hline 1917Q4 & 1919Q4 & 8 & 12 & 20 & 16 \\
\hline 1920Q4 & 1921Q4 & 4 & 4 & 8 & 12 \\
\hline 1924Q4 & 1926Q4 & 8 & 12 & 20 & 16 \\
\hline 1927Q4 & 1928Q4 & 4 & 4 & 8 & 12 \\
\hline 1929Q4 & 1932Q4 & 12 & 4 & 16 & 8 \\
\hline 1937Q4 & 1938Q4 & 4 & 20 & 24 & 32 \\
\hline 1943Q4 & 1945Q4 & 8 & 20 & 28 & 24 \\
\hline 1946Q4 & 1947Q4 & 4 & 4 & 8 & 12 \\
\hline 1951Q4 & 1952Q4 & 4 & 16 & 20 & 20 \\
\hline 1956Q4 & 1959Q4 & 12 & 16 & 28 & 20 \\
\hline 1960Q4 & 1962Q4 & 8 & 4 & 12 & 16 \\
\hline 1963Q4 & 1967Q4 & 16 & 4 & 20 & 12 \\
\hline 1968Q4 & 1969Q4 & 4 & 4 & 8 & 20 \\
\hline 1970Q4 & 1972Q4 & 8 & 4 & 12 & 8 \\
\hline 1973Q4 & 1974Q4 & 4 & 4 & 8 & 12 \\
\hline 1977Q4 & 1978Q4 & 4 & 12 & 16 & 16 \\
\hline 1979Q4 & 1982Q4 & 12 & 4 & 16 & 8 \\
\hline 1983Q4 & 1984Q4 & 4 & 4 & 8 & 16 \\
\hline 1987Q4 & 1990Q4 & 12 & 12 & 24 & 16 \\
\hline 1991Q4 & 1997Q4 & 24 & 4 & 28 & 16 \\
\hline 1998Q4 & 1999Q4 & 4 & 4 & 8 & 28 \\
\hline 2001Q4 & 2002Q4 & 4 & 8 & 12 & 12 \\
\hline 2003Q4 & 2004Q4 & 4 & 4 & 8 & 8 \\
\hline 2006Q4 & 2009Q4 & 12 & 8 & 20 & 12 \\
\hline 2010Q4 & 2011Q4 & 4 & 4 & 8 & 16 \\
\hline 2012Q4 & & & 4 & & 8 \\
\hline
\end{tabular}

Duration

(in quarters)

Expansion

Contraction

7

Amplitudes (in \%)

Expansion

Cumulation (in \%) 


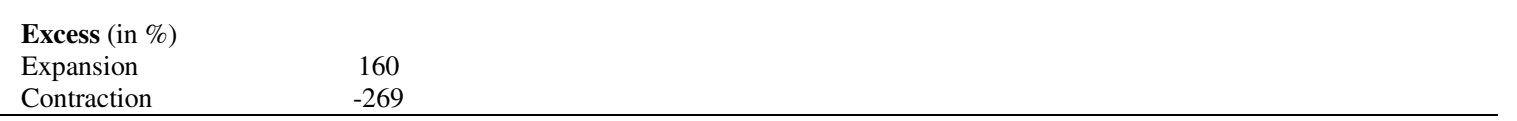

Source: Authors' own research

We isolate 33 peaks and 32 troughs in the coal cycles during 1700-2018. Cycles in coal consumption did not dominate from 1700 to 1900, with most of the coal cycles registering between 1900-2012. After 2012, coal consumption registered a steep and continuing contraction phase with no revival in sight. For comparison, the average contraction phase over the whole period is seven quarters, and the last contraction phase alone, after 2012, is lasting for six years now. The role of coal in the UK economic activity is certainly becoming less important, and there is no sign of turning back. Coal as an energy source is the one taking the biggest hit in the UK energy transition since 1960 (Figure 3).

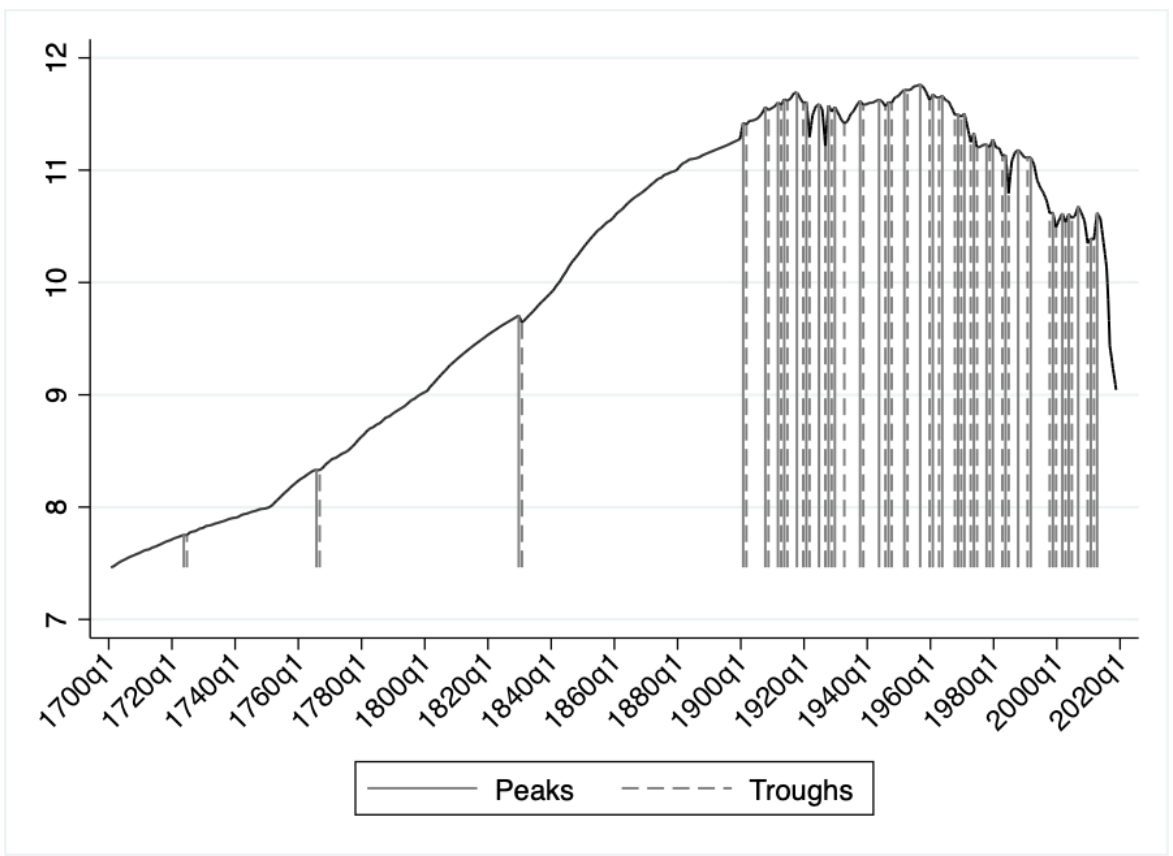

Source: Authors' own research

Fig. 3. Turning Points in the UK Coal Consumption, 1700-2018 (coal cycles)

For natural gas consumption, we use data since 1960 when gas consumption share in total energy consumption was about 3\% (1960), reaching 39.2\% in 2018. The gas consumption curve in the UK from 1700 to 2018 is exponential, with close to zero consumption from 1700 to 1900 with the fastest growth after 1960. Table 3 shows gas energy cycles characteristics for the UK.

Tab. 2. Turning Points and Gas Cycles in the UK from 1700 to 2018

\begin{tabular}{|c|c|c|c|c|c|}
\hline \multicolumn{2}{|c|}{ REFERENCE DATES } & \multicolumn{4}{|c|}{ DURATIONS IN QUARTERS } \\
\hline \multirow[t]{2}{*}{ Peak } & \multirow[t]{2}{*}{ Trough } & \multirow{2}{*}{$\begin{array}{c}\text { Contraction } \\
\text { Peak to Trough }\end{array}$} & \multirow{2}{*}{$\begin{array}{c}\text { Expansion } \\
\text { Previous Trough } \\
\text { to this Peak }\end{array}$} & \multicolumn{2}{|c|}{ Cycle } \\
\hline & & & & $\begin{array}{c}\text { Trough from } \\
\text { Previous Trough }\end{array}$ & $\begin{array}{c}\text { Peak from } \\
\text { Previous Peak }\end{array}$ \\
\hline & 1961Q4 & & & & \\
\hline 1964Q1 & 1964Q2 & 1 & 9 & 10 & \\
\hline 1979Q4 & 1980Q4 & 4 & 62 & 66 & 63 \\
\hline 1981Q4 & 1982Q4 & 4 & 4 & 8 & 8 \\
\hline 1987Q4 & 1989Q4 & 8 & 20 & 28 & 24 \\
\hline 1991Q4 & 1992Q4 & 4 & 8 & 12 & 16 \\
\hline 2000Q4 & 2002Q4 & 8 & 32 & 40 & 36 \\
\hline 2004Q4 & 2006Q4 & 8 & 8 & 16 & 16 \\
\hline 2008Q4 & 2009Q4 & 4 & 8 & 12 & 16 \\
\hline 2010Q4 & 2014Q4 & 16 & 4 & 20 & 8 \\
\hline 2016Q4 & 2017Q4 & 4 & 8 & 12 & 24 \\
\hline
\end{tabular}




\begin{tabular}{lc}
$\begin{array}{l}\text { Duration } \\
\text { (in quarters) }\end{array}$ \\
Expansion \\
Contraction & 18.2 \\
Amplitudes (in \%) & 6.66 \\
Expansion & \\
Contraction & 91.5 \\
Cumulation (in \%) & -7.27 \\
Expansion & \\
Contraction & 3507.8 \\
Excess (in \%) & -51.9 \\
Expansion & \\
Contraction & -718.6 \\
\hline
\end{tabular}

Source: Authors' own research

We isolate ten peaks and eleven troughs in the gas cycles (Figure 4). Turning points in Table 2 and Figure 4 are fitting well the actual gas consumption data in the UK. That gives the opportunity to approximate the dynamics of gas cycles with a high level of confidence. The study identifies ten full gas cycles from 1960 to 2018 . The mean duration of expansion is 18.2 quarters and contraction phase 6.66 quarters. The standard deviation for the contraction phase is 3.96 and 17.2 for expansion. The longest recession lasted 16 quarters and the longest expansion 62 quarters after 1964Q2. The expansion phase is considerably longer to contraction following a general asymmetric dynamic as in business cycles. Upswing (expansionary phase) displays positive duration dependence with mean duration 18.20 to 17.2 standard deviations. Contraction episodes show a mean duration of 6.66 to 3.96 standard deviation. Both expansion and contraction phases in gas consumption display positive duration dependence (mean duration > standard deviation). That suggests, both phases show a higher probability to end with duration (non-persistence). Average cumulative losses for contraction are $-51.9 \%$ and gains during expansion $3507.8 \%$. Cumulative losses in the contraction phase are significantly lower than gains. The highest expansion amplitude is $91.5 \%$, and contraction $-7.27 \%$. We observe a considerably larger depth of the expansion phase. Negative divergence (-718.6) during expansion point to sluggish recovery from the start and (-269.3) swift decline at the start of the contraction period.

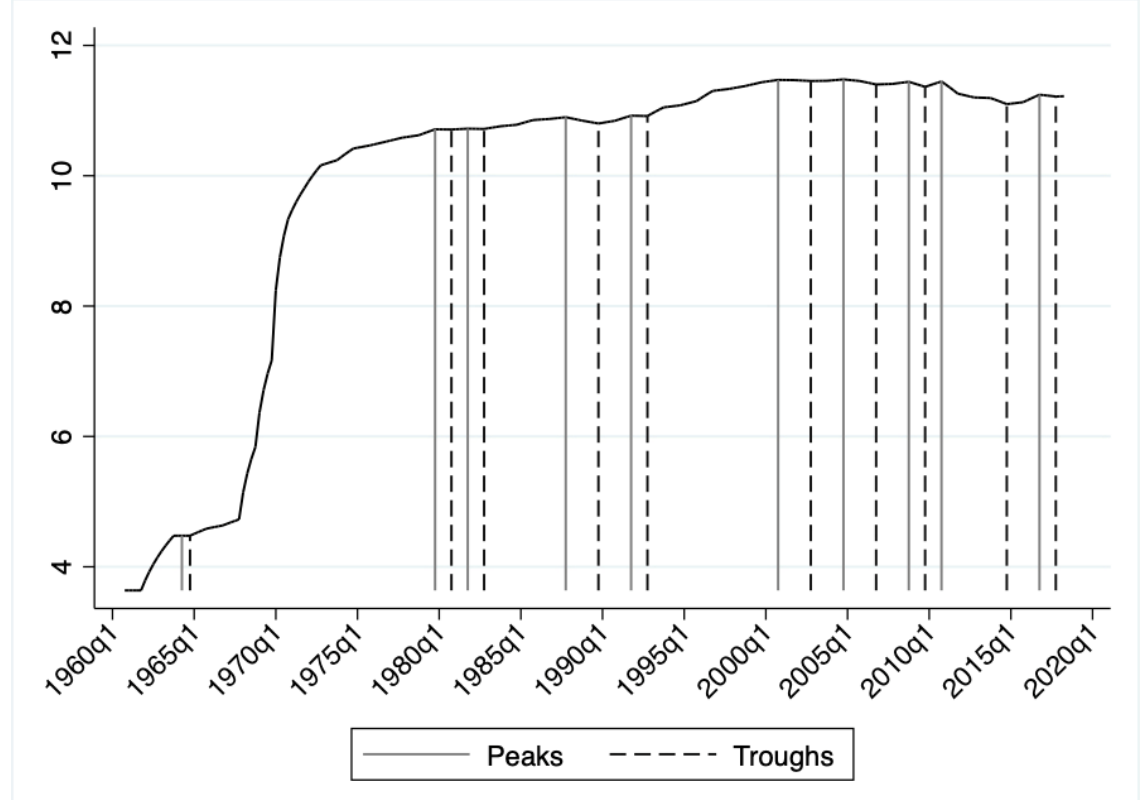

Fig. 4. Turning Points in the UK Natural Gas Consumption, 1700-2018 (gas cycles)

Source: Authors' own research

Our model separates 68 peaks and 68 troughs in the hydro energy consumption (Figure 5), while in Table 3, turning points are presented and discussed. 


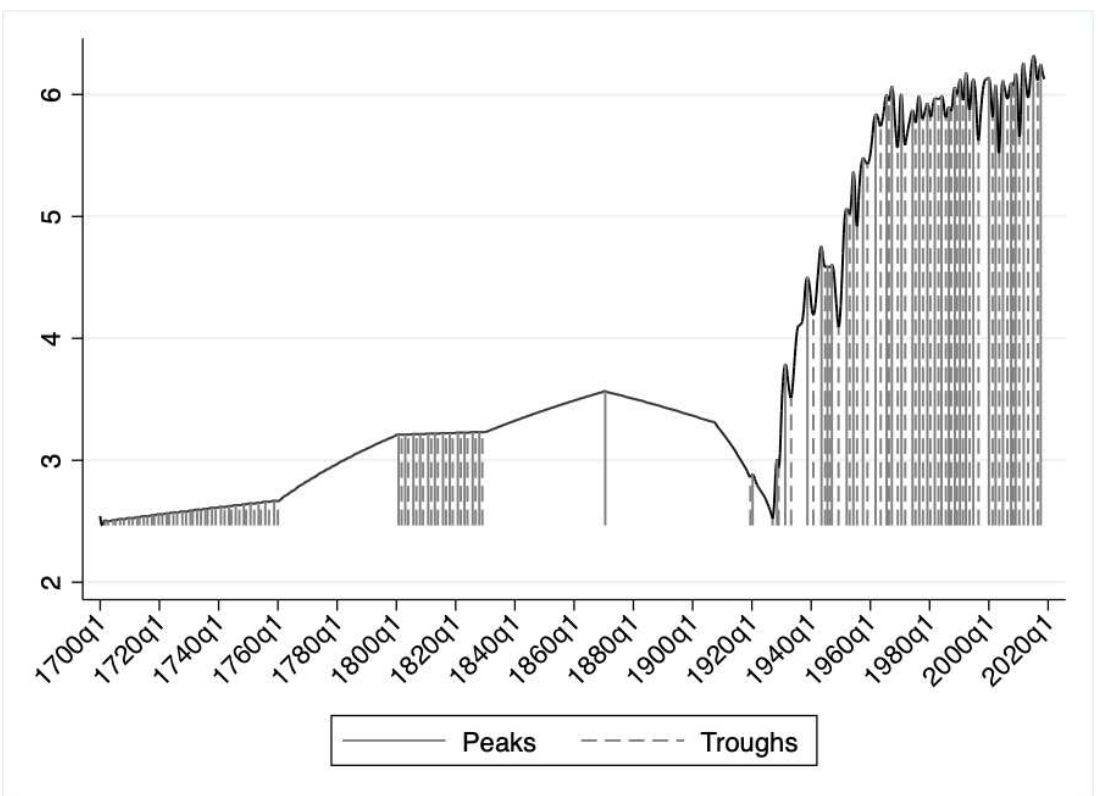

Fig. 5. Turning Points in the UK Hydro Energy Consumption, 1700-2018 (hydro cycles)

Source: Authors' own research

Figure 5 displays three distinct intervals in the hydro energy consumption from 1700-2018. The first interval is from 1700 to 1760 , the second lasting from 1800 to 1830 and the third from 1920 to 2018 . The majority of the registered turning points fall into these three intervals.

Tab. 3. Turning Points and Hydro Energy Cycles in the UK from 1700 to 2018

\begin{tabular}{|c|c|c|c|c|c|}
\hline \multicolumn{2}{|c|}{ REFERENCE DATES } & \multicolumn{4}{|c|}{ DURATIONS IN QUARTERS } \\
\hline \multirow[t]{2}{*}{ Peak } & \multirow[t]{2}{*}{ Trough } & \multirow{2}{*}{$\begin{array}{c}\text { Contraction } \\
\text { Peak to Trough }\end{array}$} & \multirow{2}{*}{$\begin{array}{c}\text { Expansion } \\
\text { Previous Trough } \\
\text { to this Peak }\end{array}$} & \multicolumn{2}{|c|}{ Cycle } \\
\hline & & & & $\begin{array}{c}\text { Trough from } \\
\text { Previous Trough }\end{array}$ & $\begin{array}{c}\text { Peak from } \\
\text { Previous Peak }\end{array}$ \\
\hline 1701Q4 & 1700Q4 & 4 & & & \\
\hline 1704Q3 & 1702Q4 & 7 & 15 & 8 & 11 \\
\hline 1706Q4 & 1705Q2 & 6 & 16 & 10 & 9 \\
\hline 1709Q4 & 1708Q1 & 7 & 18 & 11 & 12 \\
\hline $1712 Q 3$ & 1711Q1 & 6 & 18 & 12 & 11 \\
\hline 1714Q4 & 1713Q2 & 6 & 15 & 9 & 9 \\
\hline 1717Q3 & 1716Q1 & 6 & 17 & 11 & 11 \\
\hline 1719Q4 & 1718Q2 & 6 & 15 & 9 & 9 \\
\hline $1722 Q 3$ & 1721Q1 & 6 & 17 & 11 & 11 \\
\hline 1724Q4 & $1723 \mathrm{Q} 2$ & 6 & 15 & 9 & 9 \\
\hline $1727 \mathrm{Q} 4$ & 1726Q1 & 7 & 18 & 11 & 12 \\
\hline 1730Q3 & 1729Q1 & 6 & 18 & 12 & 11 \\
\hline $1732 \mathrm{Q} 4$ & 1731Q2 & 6 & 15 & 9 & 9 \\
\hline 1735Q3 & 1734Q1 & 6 & 17 & 11 & 11 \\
\hline 1737Q4 & 1736Q2 & 6 & 15 & 9 & 9 \\
\hline 1740Q4 & 1739Q1 & 7 & 18 & 11 & 12 \\
\hline 1743Q3 & 1742Q1 & 6 & 18 & 12 & 11 \\
\hline 1745Q4 & 1744Q2 & 6 & 15 & 9 & 9 \\
\hline 1748Q3 & 1747Q1 & 6 & 17 & 11 & 11 \\
\hline 1750Q4 & 1749Q2 & 6 & 15 & 9 & 9 \\
\hline 1753Q3 & 1752Q1 & 6 & 17 & 11 & 11 \\
\hline $1755 \mathrm{Q} 4$ & 1754Q2 & 6 & 15 & 9 & 9 \\
\hline 1758Q4 & 1757Q1 & 7 & 18 & 11 & 12 \\
\hline $1800 \mathrm{Q} 4$ & 1760Q1 & 163 & 175 & 12 & 168 \\
\hline 1803Q1 & 1801Q4 & 5 & 172 & 167 & 9 \\
\hline
\end{tabular}




\begin{tabular}{|c|c|c|c|c|c|}
\hline 1805Q4 & 1804Q1 & 7 & 16 & 9 & 11 \\
\hline 1808Q1 & 1806Q4 & 5 & 16 & 11 & 9 \\
\hline 1810Q4 & 1809Q1 & 7 & 16 & 9 & 11 \\
\hline 1813Q1 & 1811Q4 & 5 & 16 & 11 & 9 \\
\hline 1815Q4 & 1814Q1 & 7 & 16 & 9 & 11 \\
\hline 1818Q1 & 1816Q4 & 5 & 16 & 11 & 9 \\
\hline $1820 Q 4$ & 1819Q1 & 7 & 16 & 9 & 11 \\
\hline 1823Q1 & 1821Q4 & 5 & 16 & 11 & 9 \\
\hline $1825 \mathrm{Q} 4$ & 1824Q1 & 7 & 16 & 9 & 11 \\
\hline 1828Q1 & $1826 \mathrm{Q} 4$ & 5 & 16 & 11 & 9 \\
\hline 1870Q3 & 1829Q1 & 166 & 175 & 9 & 170 \\
\hline 1920Q2 & 1919Q3 & 3 & 365 & 362 & 199 \\
\hline 1928Q3 & 1927Q1 & 6 & 36 & 30 & 33 \\
\hline 1931Q2 & 1929Q1 & 9 & 17 & 8 & 11 \\
\hline 1938Q4 & 1933Q2 & 22 & 39 & 17 & 30 \\
\hline 1943Q3 & 1940Q4 & 11 & 41 & 30 & 19 \\
\hline 1945Q3 & 1944Q4 & 3 & 19 & 16 & 8 \\
\hline 1947Q1 & 1946Q2 & 3 & 9 & 6 & 6 \\
\hline 1952Q1 & 1949Q2 & 11 & 23 & 12 & 20 \\
\hline 1954Q2 & 1953Q1 & 5 & 20 & 15 & 9 \\
\hline 1957Q3 & 1955Q3 & 8 & 18 & 10 & 13 \\
\hline 1961Q4 & 1959Q1 & 11 & 25 & 14 & 17 \\
\hline 1965Q3 & 1963Q3 & 8 & 26 & 18 & 15 \\
\hline 1967Q2 & 1966Q2 & 4 & 15 & 11 & 7 \\
\hline 1970Q3 & 1969Q2 & 5 & 17 & 12 & 13 \\
\hline 1974Q2 & 1971Q4 & 10 & 20 & 10 & 15 \\
\hline 1976Q3 & 1975Q2 & 5 & 19 & 14 & 9 \\
\hline 1979Q2 & 1977Q4 & 6 & 16 & 10 & 11 \\
\hline 1981Q4 & 1980Q2 & 6 & 16 & 10 & 10 \\
\hline 1984Q1 & 1983Q1 & 4 & 15 & 11 & 9 \\
\hline 1986Q3 & 1985Q3 & 4 & 14 & 10 & 10 \\
\hline 1988Q3 & 1987Q2 & 5 & 12 & 7 & 8 \\
\hline 1990Q2 & 1989Q2 & 4 & 12 & 8 & 7 \\
\hline 1992Q2 & 1991Q2 & 4 & 12 & 8 & 8 \\
\hline 1994Q4 & 1993Q3 & 5 & 14 & 9 & 10 \\
\hline 2000Q1 & 1996Q3 & 14 & 26 & 12 & 21 \\
\hline 2002Q2 & 2001Q2 & 4 & 23 & 19 & 9 \\
\hline 2004Q4 & 2003Q3 & 5 & 14 & 9 & 10 \\
\hline 2007Q3 & 2006Q2 & 5 & 16 & 11 & 11 \\
\hline 2009Q1 & 2008Q2 & 3 & 11 & 8 & 6 \\
\hline 2011Q4 & 2010Q2 & 6 & 14 & 8 & 11 \\
\hline 2015Q1 & 2013Q2 & 7 & 19 & 12 & 13 \\
\hline 2017Q3 & 2016Q3 & 4 & 17 & 13 & 10 \\
\hline
\end{tabular}

Duration

(in quarters)

Expansion 10.9

Contraction $\quad 7.79$

Amplitudes (in \%)

Expansion

Contraction

$-11.7$

Cumulation (in \%)

Expansion

Contraction

Excess (in \%) 


\begin{tabular}{lc} 
Expansion & 318.2 \\
Contraction & -280 \\
\hline
\end{tabular}

Source: Authors' own research

The mean duration of expansion is 10.9 quarters, and the contraction phase is 7.79 quarters. The standard deviation for the contraction phase is 23.5 and 27.3 for expansion. The most prolonged recession lasted 196 quarters and the longest expansion 162 quarters after 1829Q1. The expansion phase is shorter to contraction, not following general asymmetric dynamics as in business cycles. Upswing (expansionary phase) displays negative duration dependence with mean duration 10.9 to 27.3 standard deviations. Contraction episodes show a mean duration of 7.79 to 23.5 standard deviations. Both expansion and contraction phases in hydro energy consumption display negative duration dependence (mean duration $>$ standard deviation). That suggests both phases show a higher probability to continue in time (persistence). Average cumulative losses for contraction are $-102.3 \%$, and gains during expansion are $199.7 \%$. Cumulative losses in the contraction phase are significantly lower than gains. The highest expansion amplitude is $17.1 \%$, and contraction $-11.7 \%$. We observe a considerably larger depth of the expansion phase. Positive divergence (318.2\%) during expansion point to rapid recovery from the start and ($280 \%$ ) swift decline at the beginning of the contraction period.

Table 4 presents identified turning points for nuclear energy 1956-2018 (nuclear energy cycle).

Tab. 4. Turning Points and Nuclear Energy Cycles in the UK from 1700 to 2018

\begin{tabular}{|c|c|c|c|c|c|}
\hline \multicolumn{2}{|c|}{ REFERENCE DATES } & \multicolumn{4}{|c|}{ DURATIONS IN QUARTERS } \\
\hline \multirow[t]{2}{*}{ Peak } & \multirow[t]{2}{*}{ Trough } & \multirow{2}{*}{$\begin{array}{c}\text { Contraction } \\
\text { Peak to Trough }\end{array}$} & \multirow{2}{*}{$\begin{array}{c}\text { Expansion } \\
\text { Previous Trough } \\
\text { to this Peak }\end{array}$} & \multicolumn{2}{|c|}{ Cycle } \\
\hline & & & & $\begin{array}{c}\text { Trough from } \\
\text { Previous Trough }\end{array}$ & $\begin{array}{c}\text { Peak from } \\
\text { Previous Peak }\end{array}$ \\
\hline 1957Q3 & 1958Q2 & 3 & & & \\
\hline 1969Q2 & 1970Q3 & 5 & 44 & 49 & 47 \\
\hline 1972Q2 & 1973Q2 & 4 & 7 & 11 & 12 \\
\hline 1974Q3 & 1975Q3 & 4 & 5 & 9 & 9 \\
\hline 1977Q2 & 1978Q3 & 5 & 7 & 12 & 11 \\
\hline 1979Q3 & 1980Q4 & 5 & 4 & 9 & 9 \\
\hline 1985Q2 & 1986Q4 & 6 & 18 & 24 & 23 \\
\hline 1989Q2 & 1990Q3 & 5 & 10 & 15 & 16 \\
\hline 1993Q3 & 1994Q4 & 5 & 12 & 17 & 17 \\
\hline 1996Q3 & 1997Q2 & 3 & 7 & 10 & 12 \\
\hline 1998Q3 & 2000Q3 & 8 & 5 & 13 & 8 \\
\hline 2001Q3 & 2002Q3 & 4 & 4 & 8 & 12 \\
\hline 2003Q1 & 2004Q3 & 6 & 2 & 8 & 6 \\
\hline 2005Q2 & 2008Q2 & 12 & 3 & 15 & 9 \\
\hline 2009Q3 & 2010Q3 & 4 & 5 & 9 & 17 \\
\hline 2011Q3 & 2012Q3 & 4 & 4 & 8 & 8 \\
\hline 2013Q2 & 2014Q3 & 5 & 3 & 8 & 7 \\
\hline 2015Q4 & & & 5 & & 10 \\
\hline \multicolumn{6}{|l|}{$\begin{array}{l}\text { Duration } \\
\text { (in quarters) }\end{array}$} \\
\hline Expansion & 8.53 & & & & \\
\hline Contraction & 5.18 & & & & \\
\hline \multicolumn{6}{|c|}{ Amplitudes (in \%) } \\
\hline Expansion & 44.7 & & & & \\
\hline Contraction & -17.1 & & & & \\
\hline \multicolumn{6}{|c|}{ Cumulation (in \%) } \\
\hline Expansion & 948.9 & & & & \\
\hline Contraction & -52.8 & & & & \\
\hline \multicolumn{6}{|l|}{ Excess (in \%) } \\
\hline Expansion & 373.9 & & & & \\
\hline Contraction & 98.5 & & & & \\
\hline
\end{tabular}

Source: Authors' own research 
The average duration of expansion is 8.53 quarters, and the contraction phase is 5.18 quarters. The standard deviation for the contraction phase is 2.12 and 9.95 for the expansion phase. The most prolonged recession lasted 12 quarters and the longest expansion 44 quarters after 1958Q2. The expansion phase is longer than the contraction and follows the general asymmetric dynamics of business cycles. The upswing (expansion phase) shows a negative duration dependence with a mean duration of 8.53 to 9.95 standard deviations. The average (positive) duration dependence of contraction ranges from average duration 5.18 to 2.12 standard deviations (Figure 6).

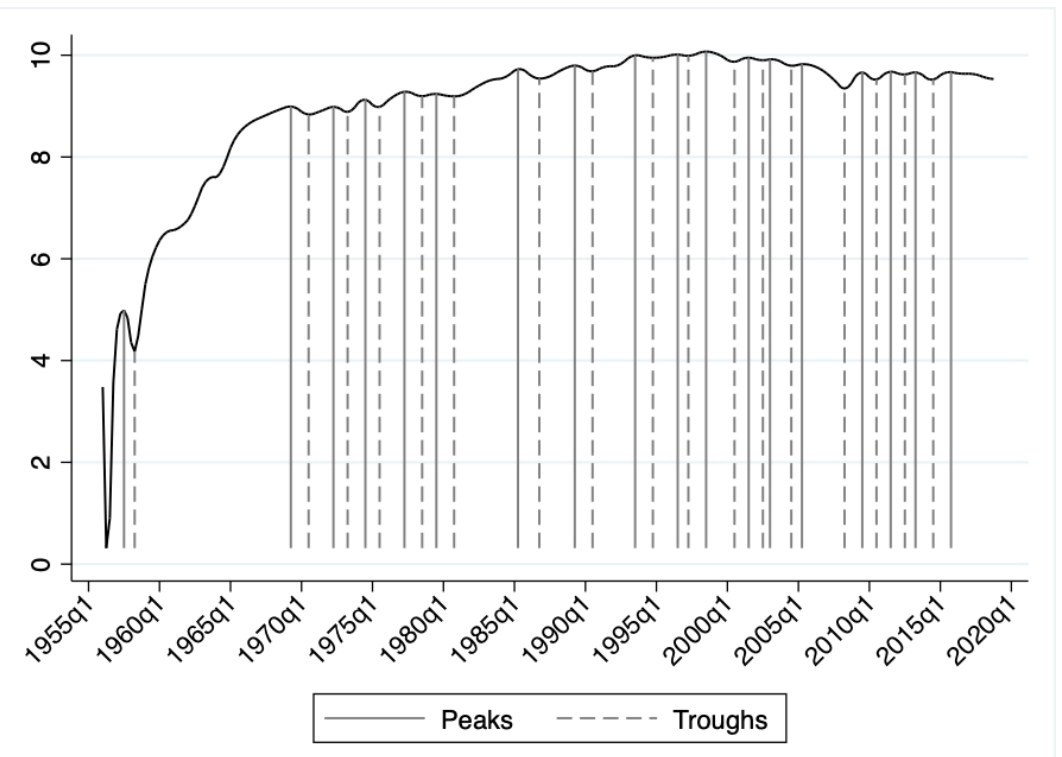

Fig. 6. Turning Points in the UK Nuclear Energy Consumption, 1700-2018 (nuclear cycles)

Source: Authors' own research

The expansion phase of nuclear energy consumption has a negative duration dependence (mean duration > standard deviation). The nuclear energy cycle contraction phase displays positive duration dependence. This suggests expansion phase shows persistence, nature, and contraction non-persistent. The average cumulative losses for contraction are $-52.8 \%$, and gains during expansion $948.9 \%$. The cumulative losses in the contraction phase are significantly lower than the gains. The highest amplitude of expansion is $44.7 \%$, and contraction $-17.1 \%$. We observe a much greater depth of the expansion phase. Positive divergences $(373.9 \%)$ during expansion indicate a rapid recovery from the beginning and (-98.5) a rapid decline at the beginning of the contraction phase.

Tab. 5. Turning Points and Oil Cycles in the UK from 1700 to 2018

\begin{tabular}{|c|c|c|c|c|c|}
\hline \multicolumn{2}{|c|}{ REFERENCE DATES } & \multicolumn{4}{|c|}{ DURATIONS IN QUARTERS } \\
\hline \multirow[t]{2}{*}{ Peak } & \multirow[t]{2}{*}{ Trough } & \multirow{2}{*}{$\begin{array}{l}\text { Contraction } \\
\text { Peak to } \\
\text { Trough }\end{array}$} & \multirow{2}{*}{$\begin{array}{c}\text { Expansion } \\
\text { Previous Trough to } \\
\text { this Peak }\end{array}$} & \multicolumn{2}{|c|}{ Cycle } \\
\hline & & & & $\begin{array}{c}\text { Trough from previous } \\
\text { Trough }\end{array}$ & $\begin{array}{c}\text { Peak } \\
\text { From previous Peak }\end{array}$ \\
\hline 1871Q3 & $1870 Q 3$ & 4 & & & \\
\hline 1874Q2 & $1872 \mathrm{Q} 2$ & 8 & 15 & 7 & 11 \\
\hline 1877Q2 & 1875Q2 & 8 & 20 & 12 & 12 \\
\hline 1879Q3 & 1878Q2 & 5 & 17 & 12 & 9 \\
\hline 1881Q3 & 1880Q2 & 5 & 13 & 8 & 8 \\
\hline 1883Q2 & 1882Q2 & 4 & 12 & 8 & 7 \\
\hline 1885Q4 & 1884Q2 & 6 & 14 & 8 & 10 \\
\hline 1889Q3 & 1886Q3 & 12 & 21 & 9 & 15 \\
\hline 1891Q3 & 1890Q1 & 6 & 20 & 14 & 8 \\
\hline 1896Q2 & 1892Q2 & 16 & 25 & 9 & 19 \\
\hline 1898Q3 & 1897Q2 & 5 & 25 & 20 & 9 \\
\hline 1902Q3 & 1899Q3 & 12 & 21 & 9 & 16 \\
\hline 1904Q4 & 1903Q2 & 6 & 21 & 15 & 9 \\
\hline 1906Q3 & 1905Q4 & 3 & 13 & 10 & 7 \\
\hline 1909Q2 & 1907Q1 & 9 & 14 & 5 & 11 \\
\hline
\end{tabular}




\begin{tabular}{|c|c|c|c|c|}
\hline 1914Q4 & 1910Q3 & 17 & 31 & 14 \\
\hline 1918Q2 & 1916Q2 & 8 & 31 & 23 \\
\hline 1921Q3 & 1919Q3 & 8 & 21 & 13 \\
\hline 1924Q2 & 1923Q1 & 5 & 19 & 14 \\
\hline 1926Q4 & 1925Q2 & 6 & 15 & 9 \\
\hline 1930Q3 & 1928Q1 & 10 & 21 & 11 \\
\hline 1934Q4 & 1931Q4 & 12 & 27 & 15 \\
\hline 1937Q2 & 1935Q2 & 8 & 22 & 14 \\
\hline 1941Q4 & 1940Q1 & 7 & 26 & 19 \\
\hline 1944Q3 & 1943Q1 & 6 & 18 & 12 \\
\hline 1956Q2 & 1946Q1 & 41 & 53 & 12 \\
\hline 1970Q2 & 1957Q2 & 52 & 97 & 45 \\
\hline 1973Q1 & 1971Q1 & 8 & 63 & 55 \\
\hline 1979Q1 & 1975Q4 & 13 & 32 & 19 \\
\hline 1982Q2 & 1981Q3 & 3 & 26 & 23 \\
\hline 1984Q3 & 1983Q2 & 5 & 12 & 7 \\
\hline 1986Q3 & 1985Q4 & 3 & 13 & 10 \\
\hline 1990Q4 & 1987Q2 & 14 & 20 & 6 \\
\hline 1993Q2 & 1991Q3 & 7 & 24 & 17 \\
\hline 1996Q3 & 1995Q2 & 5 & 20 & 15 \\
\hline 2000Q2 & 1997Q4 & 10 & 20 & 10 \\
\hline 2005Q3 & 2003Q1 & 10 & 31 & 21 \\
\hline 2017Q3 & 2013Q4 & 15 & 58 & 43 \\
\hline
\end{tabular}

Duration

(in quarters)

Expansion $\quad 10.1$

Contraction $\quad 5.6$

Amplitudes (in

$\%)$

$\begin{array}{ll}\text { Expansion } & 390 \\ \text { Contraction } & -17\end{array}$

Cumulation

(in\%)

$\begin{array}{ll}\text { Expansion } & 329 \\ \text { Contraction } & -57\end{array}$

Excess (in \%)

Expansion

470

Contraction

$-159$

Source: Authors' own research

The minimum oil cycle length is five quarters with a maximum length of fifty-five quarters (Table 5). The shortest cycle period was from 1905Q4 to 1907Q1 and the longest from 1957Q2 to 1971Q1. The average duration of expansion is 10.1 quarters, with average contraction lasting 5.6 quarters. Oil cycle exhibit a long expansion phase and shorter contractionary regime. The highest expansion amplitude measures 390\%, while contraction amplitude is $-17 \%$, with expansion amplitude significantly higher than the contraction one (asymmetric oil cycles). During the expansionary regime, cumulated gain in oil consumption amounts to $329 \%$ compared to cumulated losses $-57 \%$ (Figure 7). 


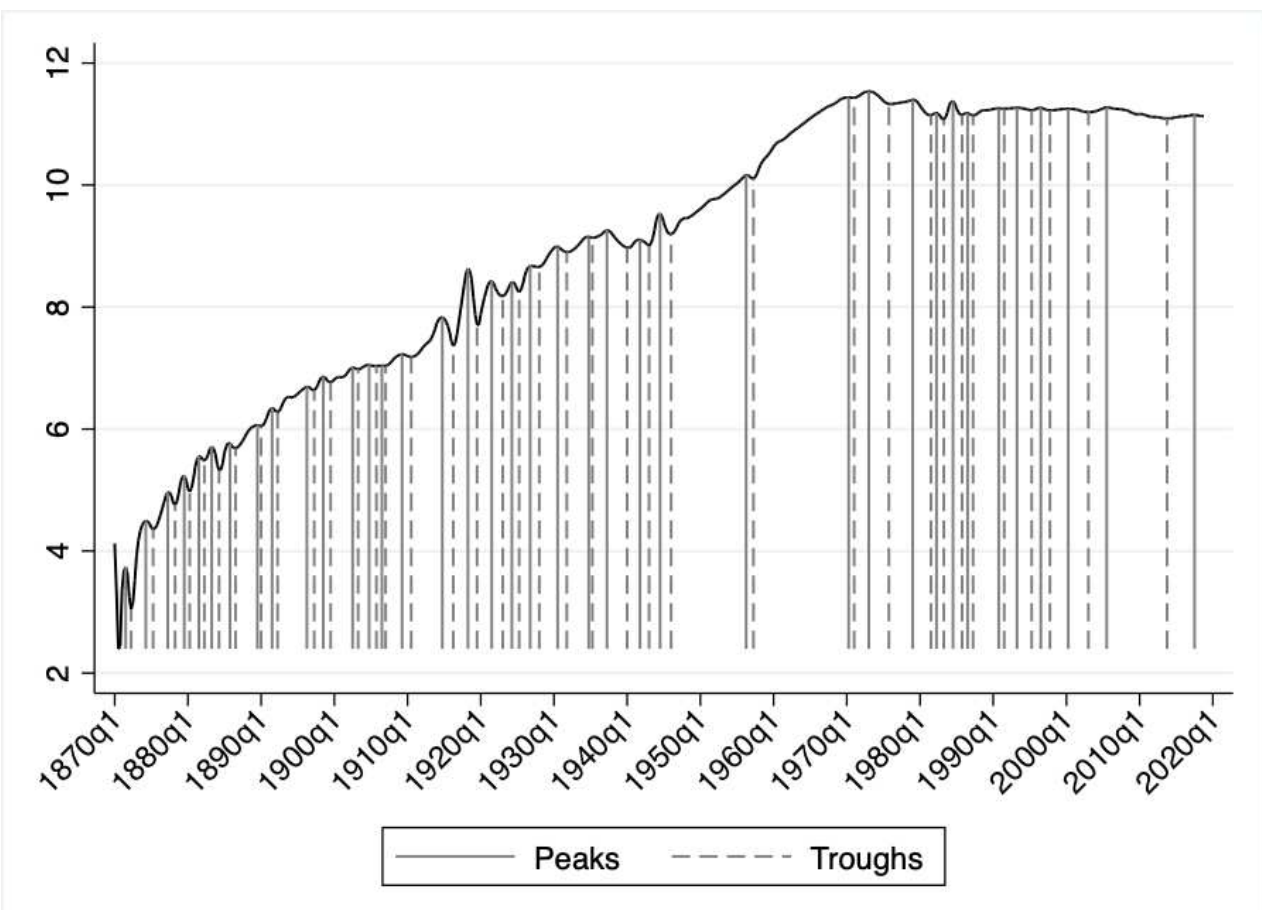

Source: Authors' own research

Fig. 7. Turning Points in the UK Oil Consumption, 1700-2018 (oil cycles)

Cycles in bioenergy consumption (Table 6) show more symmetric dynamics compared to the classical cycle. The average duration of the contraction phase (14.9 quarters) is close to the expansion phase (13.9 quarters). The average amplitude data indicate an average decline in bioenergy consumption during the contraction phase equals $-9.3 \%$. The average rise during the expansion phase in bioenergy consumption is $14.6 \%$. The loss contracted during the drop in bioenergy consumption (-244.1\%) is partly compensated by the rise in consumption during an expansion (171.9\%). High positive divergences (excess in the expansion of 237.9\%) indicate a rapid rebound in the early stages of expansion. In the early stages of a downswing, an excess measure (positive divergence $436.9 \%$ ) suggests a sluggish decline in bioenergy consumption during the contraction phase.

\begin{tabular}{|c|c|c|c|c|c|}
\hline \multicolumn{2}{|c|}{ REFERENCE DATES } & \multicolumn{4}{|c|}{ DURATIONS IN QUARTERS } \\
\hline \multirow[t]{2}{*}{ Peak } & \multirow[t]{2}{*}{ Trough } & \multirow{2}{*}{$\begin{array}{l}\text { Contraction } \\
\text { Peak to } \\
\text { Trough }\end{array}$} & \multirow{2}{*}{$\begin{array}{c}\text { Expansion } \\
\text { Previous Trough to } \\
\text { this Peak }\end{array}$} & \multicolumn{2}{|c|}{ Cycle } \\
\hline & & & & $\begin{array}{l}\text { Trough from } \\
\text { previous Trough }\end{array}$ & $\begin{array}{c}\text { Peak } \\
\text { From previous Peak }\end{array}$ \\
\hline 1702Q2 & 1701Q3 & 3 & & & \\
\hline 1704Q2 & 1703Q3 & 3 & 11 & 8 & 8 \\
\hline 1706Q2 & 1705Q3 & 3 & 11 & 8 & 8 \\
\hline 1710Q3 & 1709Q4 & 3 & 20 & 17 & 17 \\
\hline 1712Q1 & 1711Q2 & 3 & 9 & 6 & 6 \\
\hline 1716Q3 & 1715Q2 & 5 & 21 & 16 & 18 \\
\hline 1718Q3 & 1717Q2 & 5 & 13 & 8 & 8 \\
\hline 1720Q2 & 1719Q3 & 3 & 12 & 9 & 7 \\
\hline 1765Q4 & 1750Q2 & 62 & 185 & 123 & 182 \\
\hline 1771Q3 & 1766Q2 & 21 & 85 & 64 & 23 \\
\hline 1774Q2 & 1773Q3 & 3 & 32 & 29 & 11 \\
\hline 1777Q1 & 1775Q4 & 5 & 14 & 9 & 11 \\
\hline 1813Q1 & 1800Q2 & 51 & 149 & 98 & 144 \\
\hline 1841Q1 & 1830Q4 & 41 & 163 & 122 & 112 \\
\hline 1846Q4 & 1842Q2 & 18 & 64 & 46 & 23 \\
\hline 1854Q3 & 1847Q2 & 29 & 49 & 20 & 31 \\
\hline 1857Q2 & 1855Q3 & 7 & 40 & 33 & 11 \\
\hline 1860Q4 & 1858Q3 & 9 & 21 & 12 & 14 \\
\hline
\end{tabular}




\begin{tabular}{|c|c|c|c|c|c|}
\hline 1873Q3 & 1861Q4 & 47 & 60 & 13 & 51 \\
\hline 1875Q3 & 1874Q2 & 5 & 55 & 50 & 8 \\
\hline 1877Q3 & 1876Q3 & 4 & 13 & 9 & 8 \\
\hline 1881Q3 & 1879Q1 & 10 & 20 & 10 & 16 \\
\hline 1883Q3 & 1882Q1 & 6 & 18 & 12 & 8 \\
\hline 1900Q3 & 1886Q2 & 57 & 74 & 17 & 68 \\
\hline 1902Q3 & 1901Q2 & 5 & 65 & 60 & 8 \\
\hline 1904Q2 & 1903Q3 & 3 & 12 & 9 & 7 \\
\hline 1907Q3 & 1906Q1 & 6 & 16 & 10 & 13 \\
\hline 1911Q2 & 1908Q4 & 10 & 21 & 11 & 15 \\
\hline 1917Q1 & 1914Q2 & 11 & 33 & 22 & 23 \\
\hline 1920Q2 & 1919Q1 & 5 & 24 & 19 & 13 \\
\hline 1922Q4 & 1921Q3 & 5 & 15 & 10 & 10 \\
\hline 1925Q1 & 1923Q2 & 7 & 14 & 7 & 9 \\
\hline 1927Q3 & 1926Q2 & 5 & 17 & 12 & 10 \\
\hline 1929Q3 & 1928Q3 & 4 & 13 & 9 & 8 \\
\hline 1937Q2 & 1931Q4 & 22 & 35 & 13 & 31 \\
\hline 1941Q1 & 1938Q3 & 10 & 37 & 27 & 15 \\
\hline 1943Q2 & 1942Q4 & 2 & 19 & 17 & 9 \\
\hline 1945Q3 & 1944Q4 & 3 & 11 & 8 & 9 \\
\hline 1953Q3 & 1948Q3 & 20 & 35 & 15 & 32 \\
\hline 1990Q4 & 1989Q1 & 7 & 169 & 162 & 14 \\
\hline 1994Q4 & 1991Q2 & 14 & 23 & 9 & 16 \\
\hline 2006Q1 & 1995Q2 & 43 & 59 & 16 & 45 \\
\hline \multirow[t]{2}{*}{ 2010Q4 } & 2007Q1 & 15 & 62 & 47 & 19 \\
\hline & 2011Q2 & & & 17 & \\
\hline
\end{tabular}

Duration

(in quarters)

Expansion $\quad 13.9$

Contraction $\quad 14.9$

Amplitudes (in \%)

Expansion

Contraction

Cumulation (in \%)

Expansion

Contraction

Excess (in \%)

Expansion

237.9

Contraction 439.6

Source: Authors' own research

Our study separates 38 peaks and 38 troughs in the bioenergy consumption with a standard deviation for the contraction phase of 30.9 and 16.9 for expansion (Table 5). 


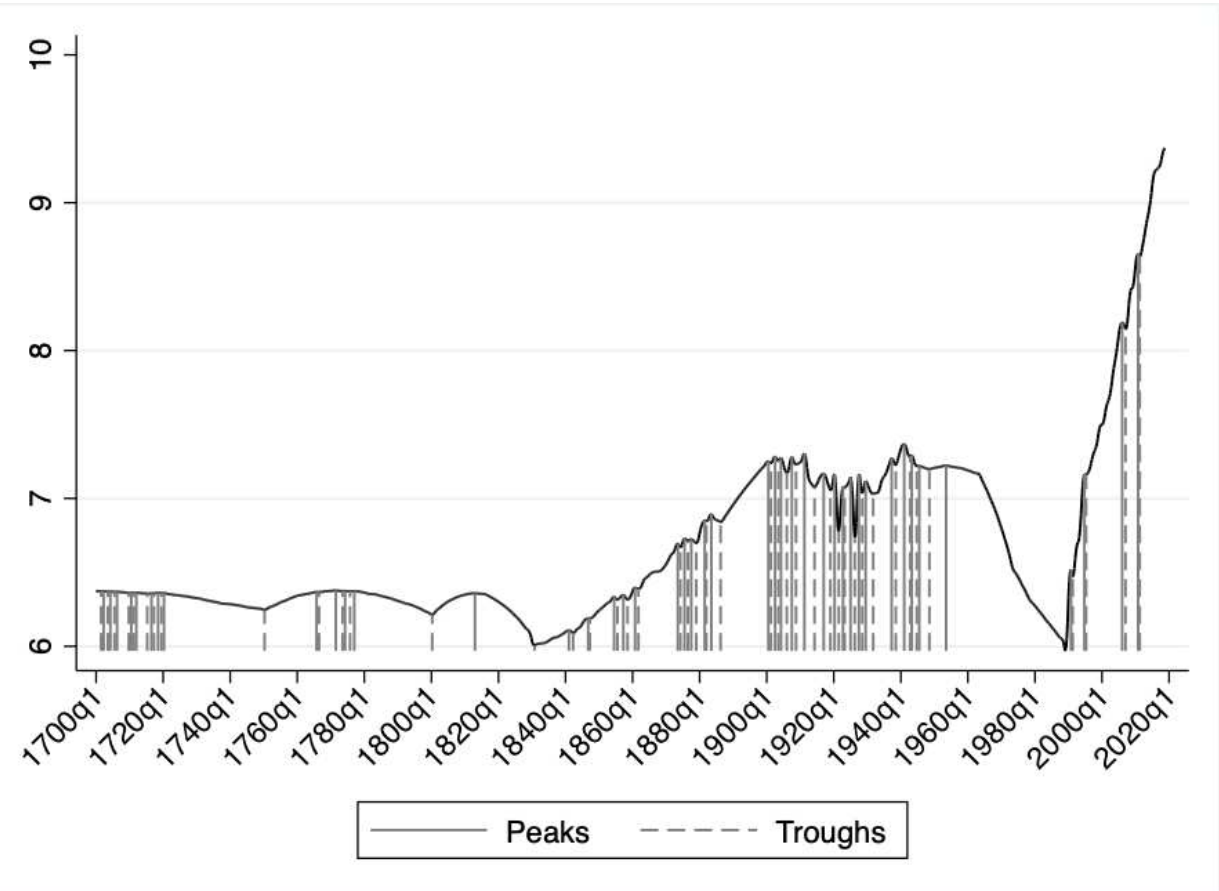

Fig. 8. Turning Points in the UK Bioenergy Consumption, 1700-2018 (bioenergy cycles) Source: Authors' own research

Tab. 7. Turning Points and Wind Energy Cycles in the UK from 1700 to 2018

\begin{tabular}{|c|c|c|c|c|c|}
\hline \multicolumn{2}{|c|}{ REFERENCE DATES } & \multicolumn{4}{|c|}{ DURATIONS IN QUARTERS } \\
\hline \multirow[t]{2}{*}{ Peak } & \multirow[t]{2}{*}{ Trough } & \multirow{2}{*}{$\begin{array}{c}\text { Contraction } \\
\text { Peak to Trough }\end{array}$} & \multirow{2}{*}{$\begin{array}{c}\text { Expansion } \\
\text { Previous Trough } \\
\text { to this Peak } \\
\end{array}$} & \multicolumn{2}{|c|}{ Cycle } \\
\hline & & & & $\begin{array}{c}\text { Trough from } \\
\text { Previous Trough }\end{array}$ & $\begin{array}{c}\text { Peak from } \\
\text { Previous Peak }\end{array}$ \\
\hline 1700Q4 & 1702Q4 & 8 & & & \\
\hline 1793Q4 & 1796Q4 & 12 & 364 & 376 & 372 \\
\hline 1805Q4 & 1806Q4 & 4 & 36 & 40 & 48 \\
\hline 1816Q4 & $1817 \mathrm{Q} 4$ & 4 & 40 & 44 & 44 \\
\hline 1818Q4 & $1827 \mathrm{Q} 4$ & 36 & 4 & 40 & 8 \\
\hline $1828 \mathrm{Q} 4$ & 1830Q4 & 8 & 4 & 12 & 40 \\
\hline $1842 Q 4$ & $1844 \mathrm{Q} 4$ & 8 & 48 & 56 & 56 \\
\hline $1868 Q 4$ & 1873Q4 & 20 & 96 & 116 & 104 \\
\hline 1876Q4 & 1922Q4 & 184 & 12 & 196 & 32 \\
\hline 1923Q4 & 1938Q4 & 60 & 4 & 64 & 188 \\
\hline 1939Q4 & 1962Q4 & 92 & 4 & 96 & 64 \\
\hline 1963Q4 & 1966Q4 & 12 & 4 & 16 & 96 \\
\hline 1968Q4 & 1973Q4 & 20 & 8 & 28 & 20 \\
\hline 1974Q4 & 1983Q4 & 36 & 4 & 40 & 24 \\
\hline 2018Q2 & & & 138 & & 174 \\
\hline \multicolumn{6}{|l|}{$\begin{array}{l}\text { Duration } \\
\text { (in quarters) }\end{array}$} \\
\hline Expansion & 54.7 & & & & \\
\hline Contraction & 36 & & & & \\
\hline \multicolumn{6}{|c|}{ Amplitudes (in \%) } \\
\hline Expansion & 106 & & & & \\
\hline Contraction & -79 & & & & \\
\hline \multicolumn{6}{|c|}{ Cumulation (in \%) } \\
\hline Expansion & 7937 & & & & \\
\hline
\end{tabular}




\begin{tabular}{ll} 
Contraction & -3078 \\
Excess (in \%) & \\
Expansion & 3155 \\
Contraction & 3074 \\
\hline
\end{tabular}

Source: Authors' own research

\section{Synchronisation of business and energy cycles}

The summary of phase amplitudes, cumulated movements, and excessive cumulated movements within business cycle phases provides more information on UK business cycle characteristics (Figure 9). The maximum phase-amplitude or depth of the recorded cycle phases is recorded during the last and longest expansion and reaches a level of 31.4 percent. The recessionary period between 1819 to 1891 has the most considerable contraction amplitude of -7.5 percent. The average amplitude of an expansion is 23.9 percent higher than the amplitude of a contraction, which indicates an asymmetry between expansions and contractions. The shape of the recognised business cycle phases can be drawn from cumulated and excessive cumulated movements. The evidence presented by cumulated movement indicators suggests significant cumulated gains in output during expansions compared to the level before the turning point. Total losses recorded during contractions are much lower but not insignificant. These findings are reflected in the average cumulated movement values, 2177 percent for expansions and -56 percent for contractions, respectively. Finally, the excess cumulated movements estimated provide further information on the shape of the expansions and contractions that appear mixed. The significant positive excess $(2082 \%)$ measures suggest the actual cumulative movements and actual gain is lower in the expansion phase. During contraction, positive excess measures $(4069 \%)$ suggest that the output loss during the recession is much larger. Positive divergence in expansion points to rapid output recovery from the start of the expansion phase and slow decline during contraction (Table 8).

In the UK, the average duration of expansion is 52.1 quarters, while contractionary regimes average 8.80 quarters. This is in line with the internationally recognised business cycle characteristic of asymmetry between expansions and contractions, as shown by the much longer duration of expansionary regimes than contractionary regimes. The predicted duration of expansions and contractions is also well separated in terms of standard deviations. In addition, the evidence suggests the longest expansion lasted 65 quarters and was terminated at the beginning of the recession of 2008. Historical data show the deepest recessions lasted six quarters. Simultaneously, the most recent full-cycle recorded is the longest full-cycle measured from peak to peak, lasting 72 quarters from 1990Q1 to 2008Q1.

Tab. 8. Turning Points and Business Cycles in the UK from 1700 to 2018

\begin{tabular}{|c|c|c|c|c|c|}
\hline \multicolumn{2}{|c|}{ REFERENCE DATES } & \multicolumn{4}{|c|}{ DURATIONS IN QUARTERS } \\
\hline \multirow[t]{2}{*}{ Peak } & \multirow[t]{2}{*}{ Trough } & \multirow{2}{*}{$\begin{array}{c}\text { Contraction } \\
\text { Peak to Trough }\end{array}$} & \multirow{2}{*}{$\begin{array}{c}\text { Expansion } \\
\text { Previous Trough } \\
\text { to this Peak }\end{array}$} & \multicolumn{2}{|c|}{ Cycle } \\
\hline & & & & $\begin{array}{c}\text { Trough from } \\
\text { Previous Trough }\end{array}$ & $\begin{array}{c}\text { Peak from } \\
\text { Previous Peak }\end{array}$ \\
\hline 1701Q4 & & 4 & & & \\
\hline 1704Q4 & 1703Q2 & 4 & 16 & 12 & 12 \\
\hline 1708Q2 & 1706Q3 & 8 & 20 & 12 & 16 \\
\hline 1711Q4 & 1710Q4 & 40 & 56 & 16 & 48 \\
\hline 171Q4 & $1729 Q 4$ & 28 & 104 & 76 & 64 \\
\hline 1738Q4 & 1737Q4 & 4 & 36 & 32 & 8 \\
\hline 1742Q4 & 1740Q4 & 8 & 20 & 12 & 16 \\
\hline $1807 \mathrm{Q} 4$ & $1744 \mathrm{Q} 4$ & 252 & 268 & 16 & 260 \\
\hline $1815 \mathrm{Q} 4$ & 1808Q4 & 28 & 284 & 256 & 32 \\
\hline $1817 \mathrm{Q} 4$ & 1816Q4 & 4 & 36 & 32 & 8 \\
\hline 1891Q4 & 1819Q4 & 288 & 300 & 12 & 296 \\
\hline 1899Q4 & 1892Q4 & 28 & 320 & 292 & 32 \\
\hline 1902Q4 & 1900Q4 & 8 & 40 & 32 & 12 \\
\hline 1907Q4 & 1903Q4 & 16 & 28 & 12 & 20 \\
\hline 1916Q4 & 1908Q4 & 32 & 52 & 20 & 36 \\
\hline 1929Q4 & 1921Q4 & 32 & 84 & 52 & 52 \\
\hline 1943Q4 & 1931Q4 & 48 & 88 & 40 & 56 \\
\hline 1979Q4 & 1947Q4 & 128 & 192 & 64 & 144 \\
\hline 1990Q4 & 1981Q4 & 36 & 172 & 136 & 44 \\
\hline
\end{tabular}




\begin{tabular}{|c|c|c|c|c|c|}
\hline 2007Q4 & 1991Q4 & 64 & 104 & 40 & 68 \\
\hline 2018Q2 & 2009Q4 & 34 & 106 & 72 & 42 \\
\hline \multicolumn{6}{|l|}{$\begin{array}{l}\text { Duration } \\
\text { (in quarters) }\end{array}$} \\
\hline Expansion & 52.1 & & & & \\
\hline Contraction & 8.80 & & & & \\
\hline \multicolumn{6}{|c|}{ Amplitudes (in \%) } \\
\hline Expansion & 31.4 & & & & \\
\hline Contraction & -7.5 & & & & \\
\hline \multicolumn{6}{|c|}{ Cumulation (in \%) } \\
\hline Expansion & 2177 & & & & \\
\hline Contraction & -56 & & & & \\
\hline \multicolumn{6}{|l|}{ Excess (in \%) } \\
\hline Expansion & 2082 & & & & \\
\hline Contraction & 4069 & & & & \\
\hline
\end{tabular}

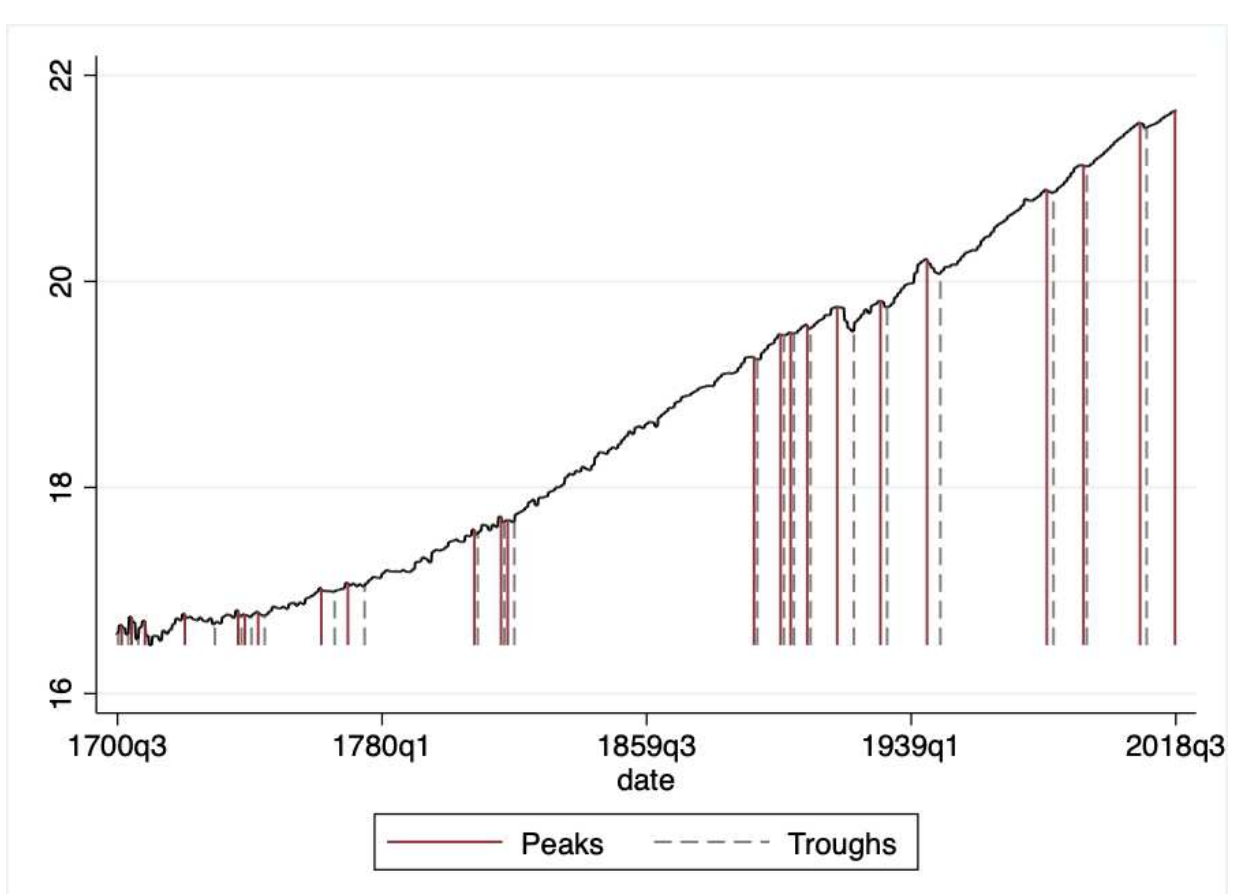

Source: Authors' own research

Fig. 9. Turning Points in the UK Output 1700-2018 (business cycles)

After dissecting the UK business cycles from 1700 to 2018, we check for synchronisation between different energy type cycles and identified business cycles. Using Harding and Pagan (2002) concordance index, we derive the concordance index between various energy cycles and business cycles in the UK during the observed period (Table 9).

Tab. 9. Concordance Statistics for Energy and Business Cycles in the UK from 1700 to 2018

\begin{tabular}{llr}
\hline & Business cycle \\
\hline & Coal & 0.62 \\
& Gas & 0.67 \\
0 & Hydro & 0.54 \\
\hline & Nuclear & 0.58 \\
& Oil & 0.61 \\
& Bioenergy & 0.58 \\
& Wind & 0.52 \\
& Solar & 0.76 \\
\hline
\end{tabular}

Source: Authors' own research 
We see energy cycles and business cycles in the UK share a pattern, with more than $50 \%$ of the time observed moving together (various energy cycles and business cycles coinciding at the same phase of the cycle). Since all the index values are above 0.50 , we conclude there is a systematic relationship in the dynamics of different energy cycles and business cycles in the UK. The relationship is particularly strong between solar energy and business cycles. The fact is not surprising since the majority of green investments is going into solar energy development. Fossil fuels still show a significant link with business cycles with coal (0.62) and gas (0.67) concordance index. Oil (0.61) is slowly losing importance, but it is still more closely related to business cycles than alternative sources of energy (Hydro 0.54, Nuclear 0.58, Bioenergy 0.58, Wind 0.52).

\section{Discussion}

Our study is novel research in the field of energy economics estimating the link between energy and business cycles. Previous studies generally look at the link between energy consumption/use and economic growth with inconclusive findings. Our study has three important findings. Primary energy consumption/use exhibits cyclical behaviour with phases like the business cycles. Cyclical patterns and phase dynamics differ across primary energy sources. Here we provide empirical evidence on the existence of turning points (phases) in energy consumption. The next finding points to the existence of a systematic relationship between energy and business cycles using the concordance index (Harding \& Pagan, 2002). Empirical results show fossil fuels sources have a significant systematic relationship with GDP dynamics in the UK. It is interesting to observe that the strength of the relationship is for all fossil fuels quite close (concordance indexes; coal 0.62, gas 0.67, oil 0.61). We see fossil fuels consumption and GDP move closely together supporting findings of (Coers \& Sanders, 2013; Mohammadi \& Parvaresh, 2014; Nachane et al., 1988; Lee \& Chang, 2008; Narayan \& Smyth, 2008; Apergis \& Payne, 2009a, 2009b, 2009c; Valadkhani \& Nguyen, 2019; Ozturk \& Acaravci, 2013).

Our third conclusion, backed up by empirical evidence here, proves that primary energy consumption/use is a driver of economic growth. Not only, but business cycles are also driven by changes in energy consumption/use (energy cycles). Thus, factors connected to energy cycles (energy prices, for example) have a strong impact on business cycles as well (Brown et al., 2003; Aminu et al., 2018; Kim \& Loungani, 1992; Schmidt \& Zimmerman, 2012; Huynh, 2016). In fact, a strong systematically link between them exists.

Policymakers and practitioners concerned with the business cycles negative effects must pay a closer look at energy cycles. Because of data bias, econometric issues (stationarity, non-linearity, causality), the nature of the business cycles remains uncertain. Like the one we use here, turning points analysis provides results on the systematic relation between energy and business cycles. Such quantitative knowledge can be used to explain deeper the dynamics observed in the business cycle. Energy cycles, which we explore in this study for the first time in the field, supply such quantitative knowledge to clarify the business cycles' nature.

The carbon emissions target for 2030 set globally will not be met. Limiting financial conditions for renewables across regions and countries, differences in the technological adoption rate, economy/industry structure are significant constraints for the energy transition. To get global support for energy transition from all economic agents, energy cycles and their impact on growth should be explained. Unravelling energy cycles in the literature and business is important for understanding how energy cycles affect managerial decisions and firms' performances to business cycles conception in time of environmental crisis.

The choice of data here was based on data availability and primary research scope. To search for the existence of energy cycles, we need long time series, so for this reason, we use data for UK. Also, the UK is a good casestudy since it offers historical data on energy consumption/use and economic dynamics (GDP) over a long time. Future studies using panel data and cross-country samples is needed to support the idea of energy cycles. Besides the modern applied econometric approach, additional insights in energy cycles can be supplied by using different business cycles filtering methods, unobserved component analysis, turning points. In the end, we also need a comprehensive global study on the existence of a global energy cycle, potential convergence, synchronisation across countries and regions.

\section{Conclusion}

Literature on energy and growth link is missing research on energy cycles, like the one we present here. A design of successful macro policy demands from policymaker's quantitative knowledge on major economic forces driving the economy. Energy consumption/use is one of these major economic forces. Understanding the nature of energy cycles help us to discover the true nature of business cycles. The link is important since energy cycles move closely together with business cycles. In fact, energy cycles have a deep impact on the economy, and they drive the business cycles. Energy cycles impact on the business cycles will be significantly deeper and larger in future, with alternative energy sources (particularly solar energy) taking a head role in primary energy use. We hope to encourage future studies on energy cycles measurement and methods, synchronisation across energy and business cycles to determine the actual effect of energy on growth. We must learn the impact of energy on growth 
in the past to foresee the effects alternative energy sources will have on growth in the future. Energy cycles are an empirical fact, and we must learn from them to fully understand business cycles and economic growth.

Future studies should focus on more countries (this study limitation) for comparison of energy cycles duration and path. Also, energy cycles determinants using logit/probit regression can be explored using data from more countries even with smaller time horizons (data since 1960). Limitations of our study do not constrain the contribution to the field since the goal of this study was to provide empirical evidence on energy cycles for the first time (not to explore them globally).

\section{References}

Altinay, G., \& Karagol, E. (2004). Structural break, unit root, and the causality between energy consumption and GDP in Turkey. Energy Economics, 26(6), 985-994. https://doi.org/ 10.1016/J.ENECO.2004.07.001

Aminu, N., Meenagh, D., \& Minford, P. (2018). The role of energy prices in the Great Recession - A two-sector model with unfiltered data. Energy Economics, 71, 14-34.https://doi.org/10.1016/J.ENECO.2018.01.030

Apergis, N., \& Payne, J. E. (2009a). Energy consumption and economic growth in Central America: Evidence from a panel cointegration and error correction model. Energy Economics, 31(2), 211-216. https://doi.org/10.1016/j.eneco.2008.09.002

Apergis, N., \& Payne, J. E. (2009b). CO2 emissions, energy usage, and output in Central America. Energy Policy, 37(8), 3282-3286. https://doi.org/10.1016/j.enpol.2009.03.048

Apergis, N., \& Payne, J. E. (2009c). Energy consumption and economic growth: Evidence from the Commonwealth of Independent States. Energy Economics, 31(5), 641-647. https://doi.org/10.1016/j.eneco.2009.01.011

Apergis, N., Payne, J. E., Menyah, K., \& Wolde-Rufael, Y. (2010). On the causal dynamics between emissions, nuclear energy, renewable energy, and economic growth. Ecological Economics, 69(11), 2255-2260. https://doi.org/10.1016/j.ecolecon.2010.06.014

Arora, V., \& Lieskovsky, J. (2016). Electricity Use as an Indicator of U.S. Economic Activity. EconStor Research Reports.

Ayres, R. U., Ayres, L. W., \& Warr, B. (2003). Exergy, power and work in the US economy, 1900 - 1998. Energy, 28(3), 219-273. https://doi.org/10.1016/S0360-5442(02)00089-0

Ayres, R. U., \& Warr, B. (2005). Accounting for growth: The role of physical work. Structural Change and Economic Dynamics, 16(2 SPEC. ISS.), 181-209. https://doi.org/10.1016/j.strueco.2003.10.003

Ayres, R., \& Voudouris, V. (2014). The economic growth enigma: Capital, labour and useful energy? Energy Policy, 64, 16-28. https://doi.org/10.1016/j.enpol.2013.06.001

Bracke, P. (2012). SBBQ: Stata module to implement the Harding and Pagan (2002) business cycle dating algorithm, Statistical Software Components S457288, Boston College Department of Economics.

Brown, S. P. A., Yücel, M. K., \& Thompson, J. (2003). Business cycles: the role of energy prices. Research Papers in Economics.

Bry, G., \& Boschan, C. (1971). Cyclical Analysis of Time Series: Selected Procedures and Computer Programs, New York, London, National Bureau of Economic Research, Columbia University Press.

Cardinale, J., \& Taylor, L. W. (2009). Economic Cycles: Asymmetries, Persistence, and Synchronization. Palgrave Macmillan Books, 308-348. https://doi.org/10.1057/9780230244405_7

Chow, G. C., \& Lin, A.-L. (1971). Best linear unbiased interpolation, distribution, and extrapolation of time series by related series. The Review of Economics and Statistics, 53(4), 372-375. https://doi.org/ $10.2307 / 1928739$

Church, R. (1986). History of the British coal industry. Volume 3. 1830-1913: Victorian pre-eminence. New York, The Clarendon Press, Oxford University Press.

Cobb, C.W., \& Douglas, P.H. (1928) A Theory of Production. American Economic Review, 18, 139-165. https://www.aeaweb.org/aer/top20/18.1.139-165.pdf

Coers, R., \& Sanders, M. (2013). The energy-GDP nexus; addressing an old question with new methods. Energy Economics, 36, 708-715. https://doi.org/10.1016/j.eneco.2012.11.015

Department for Business, Energy and Industrial Strategy. (2019). Digest of United Kingdom Energy Statistics 2019. London.

Flinn, M. W., \& Stoker, D. (1984). The history of the British coal industry. Volume 2, 1700-1830: the industrial revolution. Oxford, Clarendon Press.

Fouquet, R. (2008). Heat, Power and Light: Revolutions in Energy Services. Edward Elgar Publishing.

Fouquet, R. (2018). The Economics of Renewable Energy: Vol. I, in (Fouquet Roger, Ed.; pp. 1-948). Edward Elgar. https://blackwells.co.uk/bookshop/product/The-Economics-of-Renewable-Energy-by-RogerFouquet-editor/9781786437365 
Fouquet, R. (2019). Book review. Environmental Innovation and Societal Transitions, 33, 317-318. https://doi.org/10.1016/j.eist.2019.03.001

Fouquet, R. (2020). A Historical Energy Data Set for the UK, Grantham Research Institute on Climate Change and the Environment, London School of Economics and Political Science. https://nic.org.uk/app/uploads/Historical-Energy-Data-Final-Report.pdf

Foxon, T. J. (2018). Energy and Economic Growth: Why we need a new pathway to prosperity - (First, pp. 1-202). Routledge. https://www.routledge.com/Energy-and-Economic-Growth-Why-we-need-a-new-pathway-toprosperity/Foxon/p/book/9781138669307

Ha, J., Tan, P.-P., \& Goh, K.-L. (2018). Linear and nonlinear causal relationship between energy consumption and economic growth in China: New evidence based on wavelet analysis. Plos One, 13(5), 121.https://doi.org/10.1371/JOURNAL.PONE.0197785

Hafner, M., Tagliapietra, S. (Eds.), (2020). The Geopolitics of the Global Energy Transition, Lecture Notes in Energy. Springer, Cham. https://doi.org/10.1007/978-3-030-39066-2_1

Harding, D., \& Pagan, A. (2002). Dissecting the cycle: a methodological investigation. Journal of Monetary Economics, 49(2), 365-381. https://doi.org/10.1016/S0165-1889(02)00076-3

Harding, D., \& Pagan, A. (2003). A comparison of two business cycle dating methods. Journal of Economic Dynamics and Control, 27(9), 1681-1690. https://doi.org/10.2307/1928739

Harvey, A.C. (1990). Forecasting Structural Time Series Models and the Kalman Filter. Cambridge University Press. https://doi.org/10.1017/cbo9781107049994.

Heun, M. K., \& Brockway, P. E. (2019). Meeting 2030 primary energy and economic growth goals: Mission impossible? Applied Energy, 251, 112697. https://doi.org/10.1016/j.apenergy.2019.01.255

Huynh, B. (2016). Macroeconomic Effects of Energy Price Shocks on the Business Cycle. Macroeconomic Dynamics, 20(3), 623-642. https://doi.org/10.1017/S1365100514000455

IRENA. (2019). Renewable Energy Statistics 2019, The International Renewable Energy Agency, Abu Dhabi.

Jalil, A. (2014). Energy-growth conundrum in energy exporting and importing countries: Evidence from heterogeneous panel methods robust to cross-sectional dependence. Energy Economics, 44, 314-324. https://doi.org/10.1016/j.eneco.2014.04.015

Keen, S., Ayres, R. U., \& Standish, R. (2019). A Note on the Role of Energy in Production. Ecological Economics, 157(August 2017), 40-46. https://doi.org/10.1016/j.ecolecon.2018.11.002

Kim, I.-M., \& Loungani, P. (1992). The role of energy in real business cycle models. Journal of Monetary Economics, 29(2), 173-189.https://doi.org/10.1016/0304-3932(92)90011-P

Lee, C. C., \& Chang, C. P. (2008). Energy consumption and economic growth in Asian economies: A more comprehensive analysis using panel data. Resource and Energy Economics, 30(1), 50-65. https://doi.org/10.1016/j.reseneeco.2007.03.003

Modis, T. (2017). A hard-science approach to Kondratieffs economic cycle. Technological Forecasting and Social Change, 122, 63-70. https://doi.org/10.1016/j.techfore.2017.04.015.

Mohammadi, H., \& Parvaresh, S. (2014). Energy consumption and output: Evidence from a panel of 14 oilexporting countries. Energy Economics, 41, 41-46. https://doi.org/10.1016/j.eneco.2013.11.002

Moreau, V., \& Vuille, F. (2018). Decoupling energy use and economic growth: Counter evidence from structural effects and embodied energy in trade. Applied Energy, 215, 54-62. https://doi.org/10.1016/J.APENERGY.2018.01.044

Nachane, D. M., Nadkarni, R. M., \& Karnik, A. V. (1988). Co-integration and causality testing of the energy-GDP relationship: A cross-country study. Applied Economics, 20(11), 1511-1531. https://doi.org/10.1080/00036848800000083

Narayan, P. K., \& Smyth, R. (2008). Energy consumption and real GDP in G7 countries: New evidence from panel cointegration with structural breaks. Energy Economics, 30(5), 2331-2341. https://doi.org/10.1016/j.eneco.2007.10.006

Ozturk, I., \& Acaravci, A. (2013). The Long-run and Causal Analysis of Energy, Growth, Openness and Financial Development on Carbon Emissions in Turkey. Energy Economics, 36, 262-267. https://doi.org/10.1016/j.eneco.2012.08.025

Pollock, D.S.G. (2015). Econometric Filters. Computational Economics, 48, 669-91. https://doi.org/10.1007/s10614-015-9543-2.

Prest, A. R., \& Adams, A. A. (1954). Consumers' expenditure in the United Kingdom, 1900-1919, Studies in the National Income and Expenditure of the United Kingdom, Vol. 3. New York: Cambridge University Press.

Richard, O. O. (2012). Energy consumption and economic growth in sub-Saharan Africa: An asymmetric cointegration analysis. Economie Internationale, 129(1), 99-118. https://doi.org/10.1016/s21107017(13)60050-5

Santos, J., Domingos, T., Sousa, T., \& St. Aubyn, M. (2018). Useful Exergy Is Key in Obtaining Plausible Aggregate Production Functions and Recognizing the Role of Energy in Economic Growth: Portugal 19602009. Ecological Economics, 148, 103-120. https://doi.org/10.1016/j.ecolecon.2018.01.008 
Schmidt, T., \& Zimmermann, T. (2012). Energy Prices and Business Cycles: Lessons from a Simulated Small Open Economy Model", OECD Journal: Journal of Business Cycle Measurement and Analysis, vol. 2011/2, https://doi.org/10.1787/jbcma-2011-5kg0nvzmgfd5.

Sella, L., Vivaldo, G., Groth, A., \& Ghil, M.M. (2013). Economic Cycles and Their Synchronization: A Survey of Spectral Properties. SSRN Electronic Journal. https://doi.org/10.2139/ssrn.2380143.

Shahbaz, M., Zakaria, M., Shahzad, S. J. H., \& Mahalik, M. K. (2018). The energy consumption and economic growth nexus in top ten energy-consuming countries: Fresh evidence from using the quantile-on-quantile approach. Energy Economics, 71, 282-301. https://doi.org/ 10.1016/J.ENECO.2018.02.023

Shahbaz, M., Zakaria, M., Shahzad, S. J. H., \& Mahalik, M. K. (2018). The energy consumption and economic growth nexus in top ten energy-consuming countries: Fresh evidence from using the quantile-on-quantile approach. Energy Economics, 71, 282-301.

Sharma, S. S. (2010). The relationship between energy and economic growth: Empirical evidence from 66 countries. Applied Energy, 87(11), 3565-3574. https://doi.org/10.1016/j.apenergy.2010.06.015

Sharma, N., Smeets, B., \& Tryggestad, C. (2019). The decoupling of GDP and energy growth: A CEO guide. McKinsey, April, 1-13.

Stern, D. I., \& Kander, A. (2012). The role of energy in the industrial revolution and modern economic growth. The Energy Journal, 33(3), 125-152.https://doi.org/10.5547/01956574.33.3.5

Stern, D. I., Burke, P. J., \& Bruns, S. B. (2018). The impact of electricity on economic development: A macroeconomic perspective. International Review of Environmental and Resource Economics, 12(1), 85127. https://doi.org/10.1561/101.00000101

Stone, R., Rowe, D. A., Corlett, W.J., Hurstfield, R., Potter, M. (1954). The measurement of consumers' expenditure and behaviour in the United Kingdom, 1920-1938, Vol. 1. New York: Cambridge University Press.

Valadkhani, A., \& Nguyen, J. (2019). Long-run effects of disaggregated renewable and non-renewable energy consumption on real output. Applied Energy, 255, 113796. https://doi.org/10.1016/j.apenergy.2019.113796

Vasilev, A. (2019). The Role of Energy in a Real Business Cycle Model with an Endogenous Capital Utilization Rate in a Government Sector: Lessons from Bulgaria (1999-2016). Central European Economic Journal, 5(52), 130-141. https://doi.org/10.1515/CEEJ-2018-0011

Wolde-Rufael, Y. (2009). Energy consumption and economic growth: The experience of African countries revisited. Energy Economics, 31(2), 217-224. https://doi.org/10.1016/j.eneco.2008.11.005

Wolde-Rufael, Y. (2014). Electricity consumption and economic growth in transition countries: A revisit using bootstrap panel Granger causality analysis. Energy Economics, 44, 325-330. https://doi.org/10.1016/j.eneco.2014.04.019

Zarnowitz, V., \& Ozyildirim, A. (2006). Time series decomposition and measurement of business cycles trends and growth cycles. Journal of Monetary Economics, 53, 717-39. https://doi.org/10.1016/j.jmoneco.2005.03.015. 